\title{
Lost in the Scotch Mist - New Attributions to Tobias Smollett
}

\author{
By Donald C Shelton*
}

\begin{abstract}
The year 2021 is the tercentenary of the birth of the Scottish author, Tobias Smollett, and a suitable occasion to reassess his career; wherein conventional wisdom credits him with no literary works prior to 1746. For his early career it is necessary to look into anonymous works, with those published in London in 1730-1770 largely unresearched; and their anonymity a blurry window into history. An estimate of those separately published, or as contributions within periodicals, derives a corpus of 20,000 anonymous works: essays, poems, letters, plays, satires, novels, politics, and histories. In seeking to pierce the fog of anonymity, some 5,000 of those have been reviewed, as part of a decade of research into the early career of Smollett; with the extensive, open access, research notes freely available to scholars. That research reveals him as a prolific, but anonymous, author who contributed to London periodicals from c.1731, and published individual works from c.1733. Analysis across a range of genuine or spurious imprints, revealed a distinctive style which allows tracing of his literary DNA. From the decade of research, this essay selects a score of works describing travels or events, mainly in Scotland, around the time of the Jacobite Rebellion, and presents pro forma cases for their attribution to Smollett.
\end{abstract}

Keywords: anonymous works, spurious imprints, satire, author attribution, Scottish literature, Jacobite Rebellion, Tobias Smollett

\section{Introduction}

Tobias George Smollett (1721-1771) is largely unresearched in Scotland, with a key biography published over seventy years ago (Knapp 1949). The disinterest is despite a 1968 paper proposing a major portion of a series of thirty-one scurrilous and anonymous pamphlets about George Sackville were written by Smollett (Klukoff 1968). Now, extensive, open access, research notes reveal major gaps in Knapp's biography; including Smollett's poetry from c.1731, his 1737 arrival in London, and his prolific authorship (Shelton 2015). Although the detail is outside the scope of this paper, the notes cover works published over many genuine and spurious imprints. They illustrate Smollett's preference to hide behind pseudonyms and spurious imprints. Attributions are aided by: chronology, imprint, theme, content, style, language, satire, and polemics; e.g., a reliance on polemic terms such as; nay; in short; to be short; in a word.

Aids to Smollett attributions are remarks in Monthly Review and Critical Review. Ralph Griffiths was the nonconformist publisher of Monthly Review, who, as discussed later, published Ascanius for Smollett in 1747. However, when

\footnotetext{
*Independent Researcher, New Zealand.
} 
Smollett preferred to patronise M. Cooper and W. Owen, and also use spurious imprints, Griffiths sought to target Presbyterian Smollett. He saw Smollett as a competitor in an overcrowded market, one who hid behind pseudonyms and spurious imprints. Griffiths had a combative reputation and, as the 1750's progressed he published scathing remarks in Monthly Review, seeking to suppress Smollett's sales.

Such remarks reinforce attributions to Smollett, as with sarcastic comments by Griffiths on A Letter from a Physician; "This does not appear to have been wrote by a physician; the style and expression being too mean and inaccurate to render it digestible by readers who have any tolerable acquaintance with medicine" (Monthly Review 1752, p. 400). That barb was designed to hurt surgeon Smollett. Griffiths was aware Smollett, unqualified as a physician, but seeking an honorific title, had resorted, in 1750, to purchasing an M.D. for $£ 28$ from Marischal College, Aberdeen. As increasing negativity from Griffiths impacted on Smollett's sales, in 1756 he launched the Critical Review; Smollett's works thence forth received favourable remarks in Critical Review, whilst continuing to be demeaned in Monthly Review.

\section{A Letter from a Physician - 1752}

Items in Knapp's biography do provide pegs in the ground. For example he writes; "About 1753, Smollett set out for Scotland to see his relatives and friends, after having been separated from them some fifteen years. He appears to have left his family in Chelsea during the five months or so of his absence" (Knapp 1949, p. 160). Little is recorded about this visit; but the 1753 visit was not a holiday, as indicated by the absence of his family. The prime reason was seeking relief from consumption, as revealed by a new attribution; A Letter from a Physician (Smollett 1752C, Figure 1). As editor, Smollett states his case;

I had reduced myself into a very deplorable State of Health. I had a violent Cough, Difficulty of Breathing, a continual Tremor on my Nerves; I had coliquative Sweats, was feverish and hectick, with a continual Looseness; was totally amaciated, and every Symptom of a confirmed Consumption. ... I had a strong Inclination to be gathered to my Forefathers, and have my Remains in my own Country, not without some faint Hopes, that my native Air, so favourable to my long-liv'd Neighbours, might perhaps postpone my Journey to the other World for some few Years longer. With this View I wrote my Case to the Author of the following Letter ... (Smollett 1752C, p. v).

Smollett had a penchant for pseudo-letters, and A Letter from a Physician includes a pseudo-reply from Scotland, in the persona of a Scottish physician. The reply says of Smollett, "But you are not to conclude, that because you are a Native of this Country, that therefore you are able to endure it ... I remember before you left this Country you enjoyed as good a State of Health as most Men ... But the Case is altered with you; you are no more the hardy Highlander, you are merely English" (Smollett 1752C, p. 3). The reply discusses health improvements hoped 
from the visit. Inverness is not mentioned, but as Highlands capital was Smollett's logical destination. As aids to attribution, A Letter from a Physician includes, "In a Word, they seem intent upon reducing it into the smallest Dimensions," and, "in a Word, till his Death was as hardy as the youngest Man in the Country" (Smollett 1752C, p. vi, 16).

Smollett's consumption aids in attributing, The Ladies Magazine .. By Jasper Goodwill, of Oxford, esq; London, G. Griffith; imprint likely spurious (Smollett 1753A). Smollett is credited as major contributor, writing as Jasper Goodwill, and hiding his Glasgow origin by purporting an Oxford education. The magazine had a final issue of 10 November, 1753, which reported the consumptive and literary demise of Jasper Goodwill. The date is significant: Smollett went to Inverness in mid-1753, seeking relief from consumption. The Ladies Magazine limped on until November 1753, when it failed; as noted by Alison Adburgham;

The Publishers desire to acquaint the Public that Jasper Goodwill, Esq; Author of this Work, having for some time been afflicted with a lingering Consumption, he gave up the Ghost last Monday; so that this Number concludes Volume Four and all his Lucubrations under the name of the Ladies Magazine (Adburgham 2012).

Figure 1. Letter - Physician

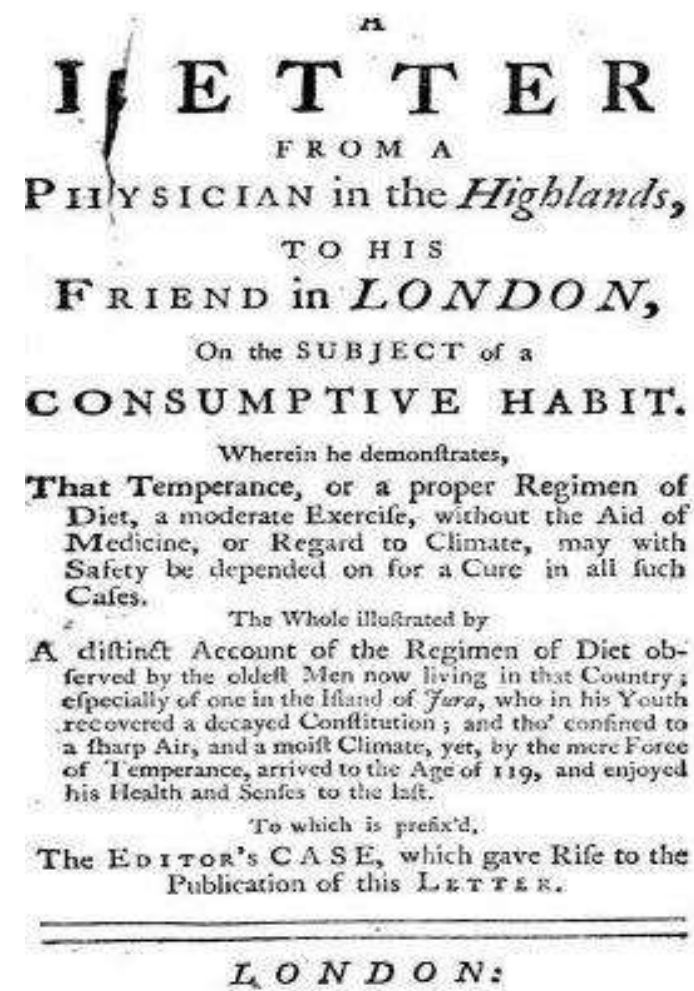

Trinted fur C. Connert, at Alajkats Heded, facing St. Duxflar's Church, Fket-fircet.

[ Price Six-prence. ] 
Figure 2. Letters from a Gentleman

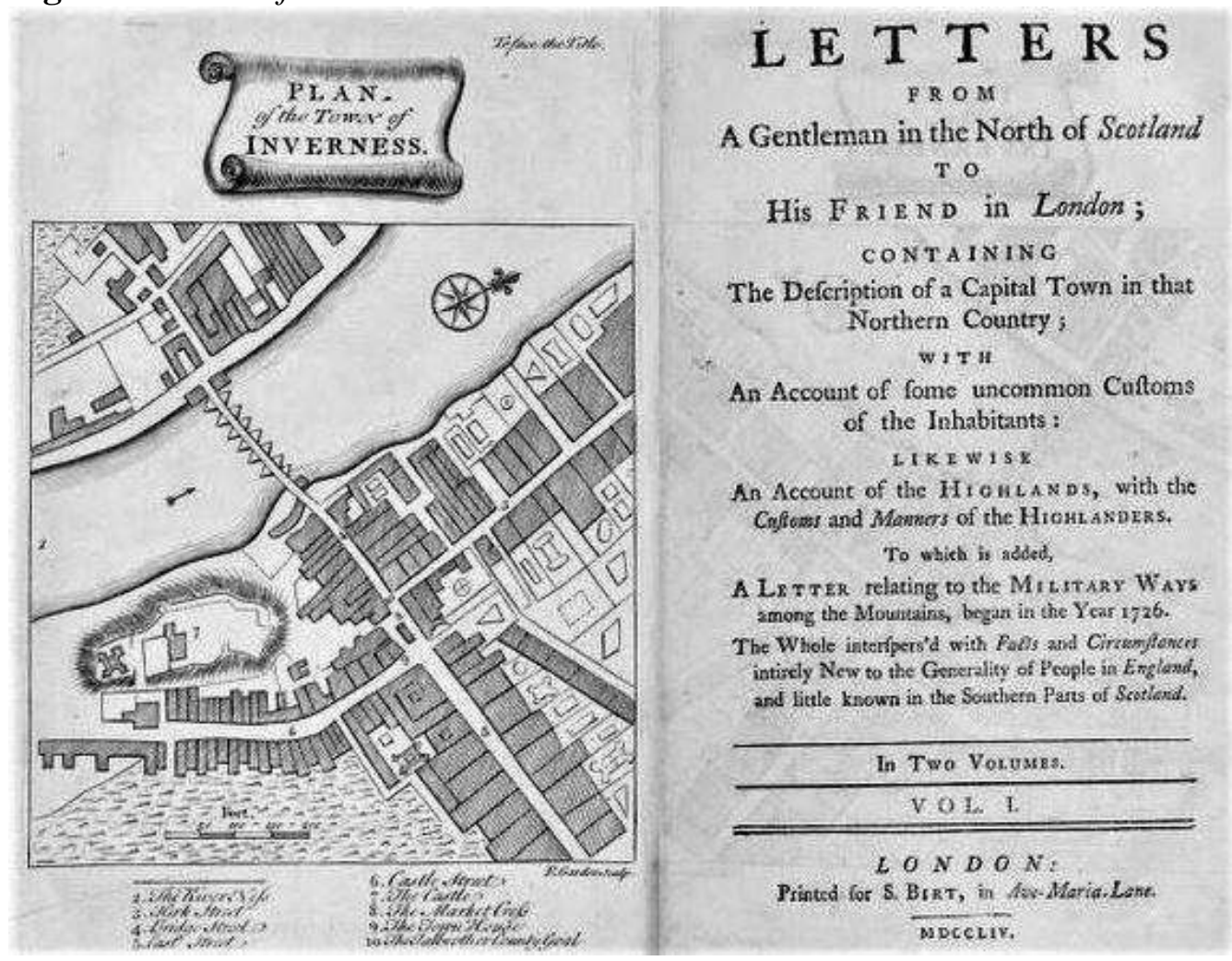

\section{Letters from a Gentleman - 1754}

With Knapp and A Letter from a Physician demonstrating Smollett was in Inverness for his health for five months in 1753, it is logical to consider what he wrote whilst there. Clues are works published in 1754; an obvious target is, Letters from a Gentleman in the North of Scotland .... London, S Birt, 1754 (Figure 2) (Smollett 1754). The work comprises Letters I-XXVI, purportedly written c.17201730, with Inverness as "the Capital Town in that Northern Country". Similarity of title to A Letter from a Physician hints at his pen, and Letter XXVI, describes his state, confirming ex-navy Smollett was there for his health; note also the polemic "to be short";

A certain officer of the army [navy], when in London, was advised by his physicians to go into the country for better air ... he resolved by gentle journeys to endeavour to reach [Fort Augustus] ... I was then in the barrack, and the next morning early I saw upon the parade, a stranger which is there an unusual sight. He was in a deep consumption, sadly emaciated, and with despair in his countenance ... I happened at that instant to be, as it were, inspired with a confidence not ordinary with me, and told him peremptorily and positively the country would cure him ... To be short he mended daily in his health, grew perfectly well in a little time, obtained leave to return to England (Smollett 1818, pp. 227-229).

Letters from a Gentleman is often attributed to an Edmund Burt. In Stepping 
Westward (Leask 2020) Nigel Leask overlooks Smollett's soundex puns, and accepts S. Birt as publisher, whilst proposing Edmund Burt as author. That is despite Leask noting; "Ironically, in Gaelic his patronymic, 'bùrt' means, 'mockery, ridicule, quizzing, joking"'. Much academic effort has been expended to establish Edmund Burt as a real person (cf. Dougal Graham, William Chaigneau, and William Horsley as discussed below). But what does that prove? It is the identity of the author that is important, not coincidental existence of a minor historical figure. In his introduction to the Georgia University edition of Smollett's, The Expedition of Humphry Clinker, Thomas Preston quotes Avrom Fleishman; with an applicable test;

The presence of the external world instead, as Fleishman continues, raises the question, "how do we respond to works which themselves insist on their reality function, which tie themselves closely to historical time and geographical space, which mix invented names with the names of actual persons, and which refer to objects that are observable in the inhabited world?" (Smollett 1990, p. xliv).

Some sources opine Edmund Burt resided in Inverness between the rebellions of 1715 and 1745, but War Office records fail to show he held military rank. Notes and Queries, 1859, p. 174, refers to Burt as author of a July 1725 letter from Edinburgh, in connection with Glasgow riots of 1725 . The letter has no reference to Burt as an engineer, but he does admit to gout; an obstacle to surveying in rough country! Others claim he was Chief Surveyor for the road building, but prudent scrutiny of Letters does not support this. The roads built by General Wade were across the eastern highlands, essentially from Crieff to Loch Ness and Inverness (Figure 5), whereas 90\% of the discussion within Letters I-XXV is a travelogue on the people and history of the western highlands. Only Letter XXVI describes the eastern roads and their construction, and appears an afterthought; describing completed roads and explaining how features were constructed.

A critical test compares Letters with Samuel Johnson's, A Journey to the Western Islands (Johnson 1775), and James Boswell's, Journal of a Tour to the Hebrides (Boswell 1785). The benchmark is the logic used by Sherlock Holmes; "Why did the dog not bark?" Letters does not extend to the Western Islands, but there are major areas of geographic overlap around Inverness. Both Johnson and Boswell itemise countless actual names of people they met and places they visited. But in Letters there are no names of actual people or locations; whereas one should expect genuine letters of c.1720-30 to contain divers names of people and locations. The reason, "the dog did not bark", i.e., Letters omits names and places, is because it satirises events during Smollett's 1753 visit. Both Leask and Sir Walter Scott accept Letters as written by Burt but, more importantly, neither Johnson nor Boswell quote from Letters in their Journals of 1775 and 1785; both being keenly aware it was a Smollett satire.

The c.1720-1730 dates of the pseudo-letters are a clue Smollett's inspiration for Letters was Defoe's three-volume travel book, A Tour Thro' the Whole Island of Great Britain (Defoe 1724); tempered by satiric mocking of Highland inhabitants, and reminiscent of Swift's Gulliver's Travels (Swift 1726). In bracketing those dates, Smollett intended readers of Letters should conclude his literary skills were 
on a par with Defoe and Swift. Smollett never met Defoe, but adopted him, along with Swift and Pope, as literary models. Defoe and Smollett were each taught rhetoric, logic and Latin grammar, and the sciences. Defoe had a parallel reluctance to reveal details about himself, and both wrote anonymously. As for Defoe, Smollett's family was a confidant of royalty; Sir James Smollett was knighted in 1698 by King William. Defoe was anti-Catholic and feared Popish plots, as did Smollett, an avid anti-Jacobite; who attacked Alexander Pope and the French for Catholicism. Defoe wrote Memoirs of a Cavalier, a model for adventures in Smollett's Ferdinand, Count Fathom (Smollett 1753C). In his Review, Defoe pioneered many features of modern newspapers; echoed by Smollett in writing for London periodicals. Smollett drew on Defoe's Review title for his Critical Review, and followed Defoe's lead in presenting opinions he did not hold. Defoe often wrote on a single theme, but adopting dissimilar polemic arguments. Smollett did the same, with opposing pamphlets, via a battling and baffling mix of spurious and genuine publishers, intended to convey the impression of vigorous public debate.

Critical analysis of Letters demonstrates the work as a travelogue. Although purporting to be a series of conversational letters, when analysed carefully, that is not the underlying structure. Instead of day to day accounts of road-building, each letter is a cultural and geographical description of an aspect of north-western highland Scotland; Smollett's accumulation of information over a period of five months, extracted from local histories, travel, and interaction with the inhabitants. A typical Smollett subterfuge is reference to people and events in Edinburgh as cover for Glasgow. Instances in Letters do give a genuine impression of Smollett residing in Inverness for several months; for example, multiple references to meeting English army officers, but as officers posted to Inverness after the Rebellion, not on road-building duty. If the author was Chief Surveyor for Wade, one would expect the letters to contain endless discussions on difficulties in plotting the route, surveying and building roads in rough country, and bad weather, together with problems in supply of labour and materials. Also progressive milestones achieved, reports of accidents, management of the workforce, and, especially, the attitudes of eastern-highland inhabitants to the soldiers, and to the road. 
Figure 3. Albania 1737

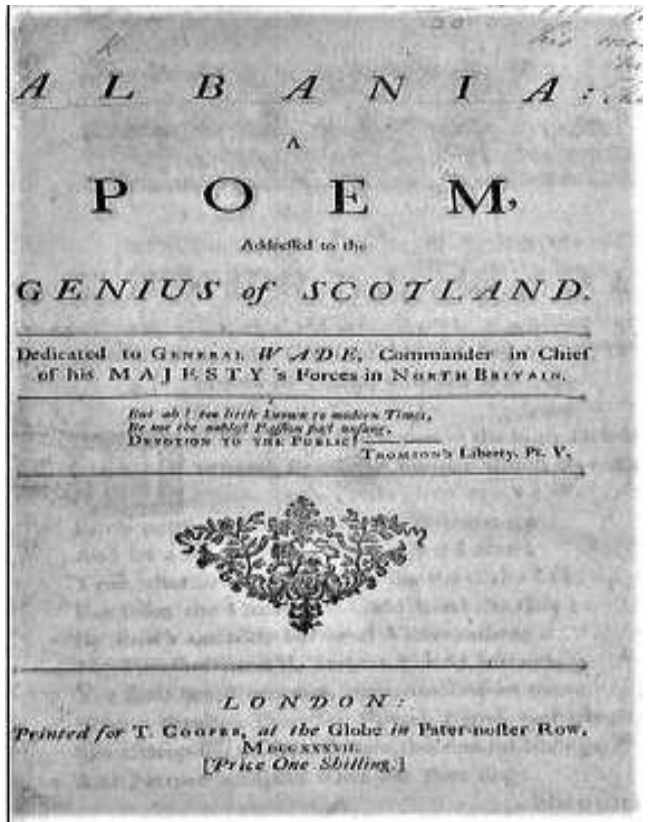

Figure 4. The Strolling Hero 1744

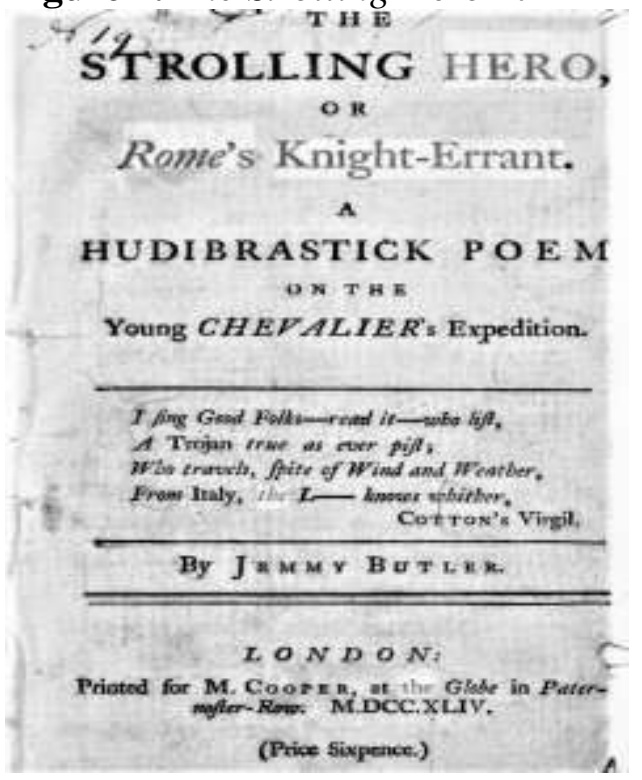

Smollett had admired Wade's efforts in Scotland even before 1753, as indicated by a poem now attributed to him, Albania, a Poem, Addressed to the Genius of Scotland, London, T. Cooper, 1737 (Figure 3) It is dedicated to General Wade but, as typical opinionated Smollett, is misleadingly, "Addressed to the Genius of Scotland"; intended to self-describe Smollett! The pamphlet includes Smollett dissimulation; on many occasions he introduced an apocryphal piece by pretending to have found a cache of letters or similar:

The above poem was wrote by a Scots clergyman some years ago, who is since dead. 
The fine spirit of poetry which it breathes, its classic air, but, above all, the noble enthusiasm he discovers for his country, cannot fail to make it agreeable to such as have a taste for that simplicity of nature and that beautiful diversification of epithets which constitute the principal excellence of antiquity (Smollett 1737).

Figure 5. A Map of Roads from Edinburgh to Inverness, Fort Augustus and Fort William, as Advertised in Scots Magazine, March, 1746, and Available to Smollett in 1746 and 1753. General Wade and his Planning of the Roads are discussed by Chantrey (2009)

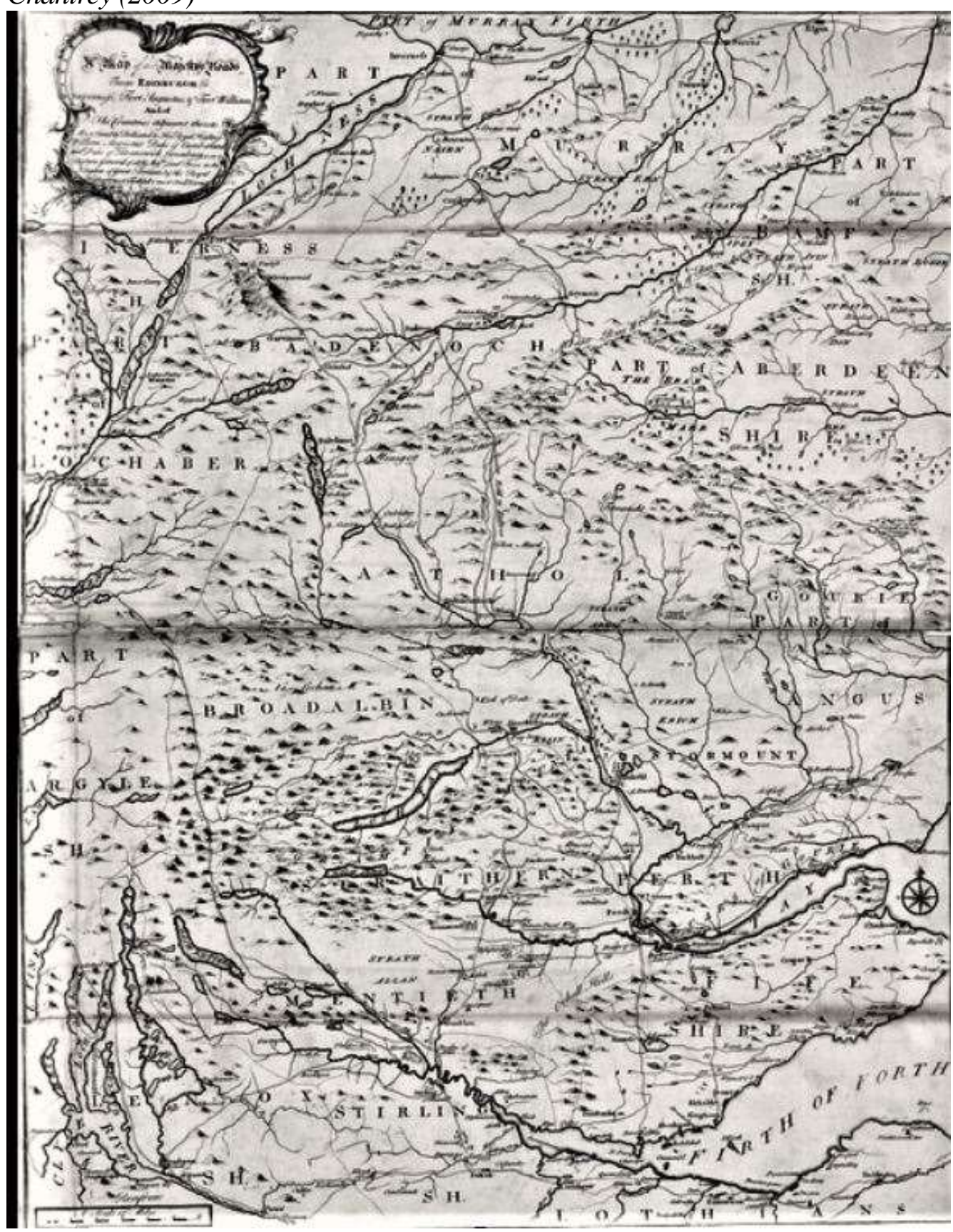

Smollett contributed to The Gentleman's Magazine and, for details of 1745, 
drew on the London Gazette, with its 1745 minutiae. Smollett alludes to the London Gazette in an anti-Jacobite poem attributed to him; The strolling hero, or, Rome's knight-errant .... By Jemmy Butler, London, M. Cooper, 1744 (Figure 4).

The Story's odd, and then, I pray,

What to my Numbers can you say;

Tho' rough and rumbling as a Coach,

They're smoother than the Prose of

And I have sure a Right to blaze it,

Who but transverse the $L \_n G_{-} z \_$te (Smollett 1744C, p. 24).

Evidence for the early career of Smollett is outside this paper, but cross-linked and detailed research shows him with surprising editorial influence at The Gentleman's Magazine and Scots Magazine, and an ability to puff his works therein, often a clue to his pen (Shelton 2015). In claiming discovery of old letters, he often left a clue any claim of age was a fiction; e.g., an ironic hint opening his puffing of Letters in The Gentleman's Magazine, July 1754, p.342; "These letters, which are said to have been written between 20 and 30 years ago, the attentive reader may perhaps suspect to be of later date".

References within Letters seek to imply it was written prior to the 1745 Jacobite Rebellion, but as a modern author might write about events prior to 1939 . In setting the letters prior to 1745 , Smollett was able to write a travelogue without being sidetracked by the overwhelming impact of matters, prior to, during, and after the 1745 rebellion. However, as extra camouflage, some excesses relayed to him about the 1745 rebellion, he extracted from events during the 1715 rebellion. As seen below, Smollett mimics Defoe's possession of a bundle of papers upon which his 1720, Memoirs of a Cavalier was based;

I found this manuscript among my father's writings, and I understand that he got them as plunder at, or after, the fight at Worcester, where he served as major of regiment of horse on the side of the Parliament. L.K. (Defoe 2006, pp. 13-14).

I am apt to imagine you may be curious to know by what Means the following Letters came to my Hands after the space of between twenty and thirty Years. ... The Person who writ them, has not set his Name to any one of them, and, it is very probable, he made Use of that Caution for Reasons given in his introductory Letter; ... if I had known the Name, in all Likelihood I might have thought myself under an obligation to conceal it (Smollett 1815).

In Letter I of Letters, Smollett also outlines his preference for anonymity;

I have several Reasons for this Precaution, which I make no doubt you will approve. First, The contrary might create Inconveniencies to me in my present Situation. It might furnish Matter for disobliging Comparisons ... And lastly, It would do me no great Honour to be known to have made a Collection of Incidents, mostly low, and sometimes disagreeable (Smollett 1815, p. 2).

Smollett used mockery within Letters to avenge his family honour against the 
Highland Jacobites. His 1753 visit was exactly 150 years after the events of 1603, when 400 men of Clan MacGregor came to Lennox to "reave and spoyle". The leaders were indicted, after they, "slauchteris, schamefullie, crewallie and barbaruslie murdreist and slew Peter Naper of Kilmahew; Johnne Buchannane of Buchlyvie; Tobias Smallet, bailzie of Dumbarten ..." After the guilty verdicts, the sentence provided, "the saidis persones to be tane to the mercat-croce of Edinburgh, and thair to be hangit upone ane gibbet quhill thay be deid; and thairefter thair heidis, legis, airmes and remanent pairtis of thair bodeis to be quarterit and put upone publict places", and all their estates to be forfeited (Pitcairn 1833, pp. 430432). Smollett's earlier poem, The Tears of Scotland (Smollett 1746F), better describes those murderous events of 1603, affecting the Smollett family, than it does Culloden in 1746.

Whilst not a native Gaelic speaker, Smollett knew 'bùrt' meant, mockery, ridicule, quizzing, joking. As a joke he published Letters anonymously with S. Birt, a real publisher, but not otherwise used by Smollett; to veil the ridicule of Highlanders in his, "collection of incidents, mostly low, and sometimes disagreeable". But, by January 1755, Smollett feared his identity was near discovery, and a risk to sales of other works. He elected to "kill off" the author of Letters, selecting another pun, Edmund Burt, as straw-man, and arranged fake obits for Burt in Scots Magazine and The Gentleman's Magazine (Figures 6 and 7).

Figure 6. Obit in Scots Magazine - 1755, p. 52

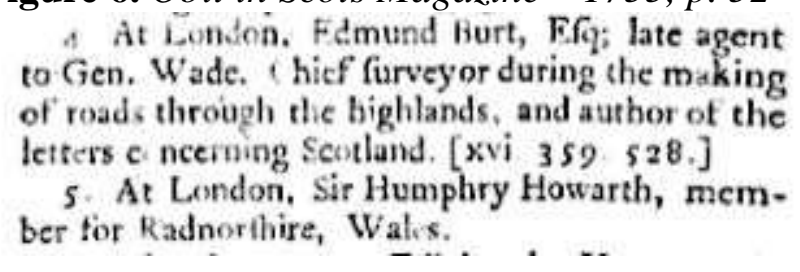

Figure 7. Obit in Gentleman's Magazine - 1755, p. 92

Beñj. Scott, Efá; of an apopleatic fit, at

Poole in Dorfer hire.

4. Edmund Burt, Efq; author of a late dc-

fcription of Scotland (See Vol. xxiv. p. 4,6 )

8. Major Matt. Draper, in S. udicy-freet.

30. Henry Ld Holyroodhoufe, at Edinburgke.

1s. Sir Tho. Trrrel. of Buckinshambirc.

The "backstory" obits introduce Burt as, "Chief surveyor during the making of roads through the highlands, and author of the letters concerning Scotland", but fall into the category of "too good to be true" (On his p. 26, n.13, Leask (2020) mistakenly, and misleadingly, claims the obit reads in lower case, "Gen. Wade, chief surveyor", to purport General Wade was chief surveyor.) Both obits refer to previous essays, a typical Smollett ploy to draw attention to earlier works. Smollett left satiric clues to his subterfuge; Burt puns Birt the publisher, with Edmund shared by the notorious book-seller Edmund Curll, and by Henry Fielding's father. With Smollett shown as author of Letters, the life of the real Burt has no relevance. 


\section{John English's Travels through Scotland - 1763}

In 1763, "Burt" was confirmed as a Smollett pseudonym, via the Monthly Review and Critical Review. The work they discussed was a scurrilous work about the Scots; John English's travels through Scotland, Containing, a curious and entertaining account of the manners and strange customs of the inhabitants. With many humorous anecdotes..., London, W. Morgan (Smollett 1763). Morgan being a spurious imprint in 1762-1763. Although he had "killed off" Burt for mockery of the Scots, Smollett accepted biased ridicule was saleable in England. To distance himself, he created a new persona, John English, to mock both Scots, and English, via enhanced bigotry. Monthly Review and Critical Review refer to Burt/Birt; and evidence Smollett's hand in both Letters from a Gentleman and John English. Monthly Review opines; "this shameless scribbler a native of some other soil," in hoping "no Englishman can be charged"; thus implying Scottish Smollett as author of John English; and confirming Letters as "his satire";

Of all the dull and stupid trash which, to our unavoidable mortification, hath passed in review before us, this surely is the dullest and most stupid; as it is also the filthiest and meanest. ... We hope, however, that no Englishman can be charged with offering so bare-faced an affront to the Public: and, indeed, from some expressions in his trumpery, we are led to conclude this shameless scribbler a native of some other soil ... As to the present dirty offender, we think it would be very proper to have him well washed in a horse-pond. Mr Birt's [sic] travels into Scotland were severely satirical upon that country, and he may possibly have made some things worse than he found them; yet ... we have known even some North-Britons who could readily forgive him his satire.... (Monthly Review 1763, p. 77)

In Critical Review, Smollett distances himself from John English's bigotry but acknowledges Burt/Birt, via a satiric red-herring claim Burt hanged himself: an allusion to the fate of those in Clan MacGregor who in 1603 had "crewallie and barbaruslie murdreist" Tobias Smallet;

The execrabllity of all execrabilities. We should not have taken notice of this performance, had it not been for a principle of humanity, which obliges us to inform the public, that it is an extract from a series of letters, in two volumes, concerning the Scotch nation, published some years ago by one B. and printed for a bookseller and namesake of his own; but it succeeded so well, that the author fairly hanged himself at his lodgings or house in Channel-Row, Westminster; a laudable example to his epitomizer! (Critical Review 1763, pp. 77-78).

\section{An Impartial History - 1746}

Scottish histories of the 1745 Jacobite Rebellion pay scant attention to Smollett, but as a Scot and a published author it had natural appeal for him; with multiple works now attributable to him. Recent research has focused on the author, Dougal Graham; like Edmund Burt, linked to Glasgow. Graham's work is claimed an eye-witness account of events during the Rebelliom, as in the Dictionary of 


\section{National Biography;}

Dougal Graham was ... much deformed, and ... when the highland army of Prince Charles Edward was on its way south in September 1745, he ... followed the prince. It is probable he was merely a camp-follower, as he can scarcely have been a soldier, but he accompanied the forces to Derby, and back to Scotland, and was present at Culloden (16 April 1746). Five months later he published A full, particular, and true Account of the Rebellion in the year 1745-1746. This work is written throughout in a rough doggerel, but is historically useful as the undoubted testimony of an eyewitness. ... Graham settled in Glasgow, and is said to have become a printer, but this is doubtful; at all events he became 'skellat', bellman or town-crier, of Glasgow about 1770 . He is described as "a bit wee gash bodie under five feet", as being lame in one leg, "with a large hunch on his back, and another protuberance on his breast" (DNB 1900).

It is also claimed Graham wrote chapbooks, as are published in, The Collected Writings of Dougal Graham, 'Skellat'Bellman of Glasgow, by George MacGregor, Glasgow, Thomas D Morison, 1883 (MacGregor 1883). This contains an advertisement from the Glasgow Courant of 29 September, 1746;

That there is to be sold by James Duncan, Printer in Glasgow ... a Book intituled $A$ full, particular, and true Account of the late Rebellion in the Year 1745 and 1746, beginning with the Pretender's Embarking for Scotland, and then an Account of every Battle, Siege, and Skirmish that has happened in either Scotland or England ... Booksellers or Packmen may have them easier from the said James Duncan, or the Author, D. Grahame (MacGregor 1883, p. 13).

\section{Figure 8. Epitaph on a Scotsman}

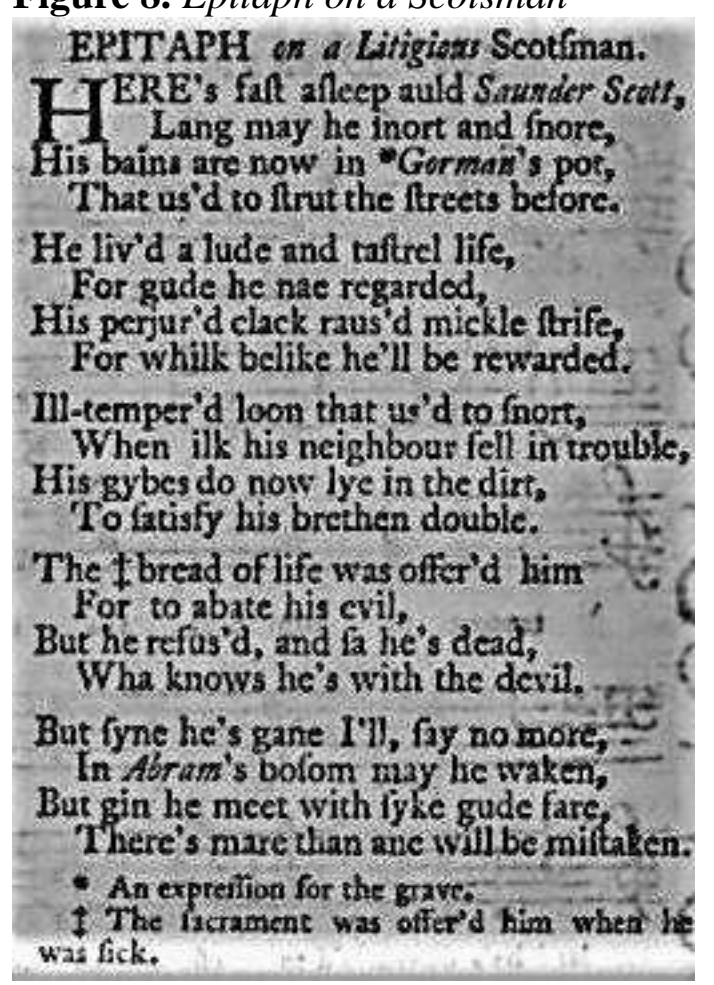


Figure 9. Rebel Musket Exercise

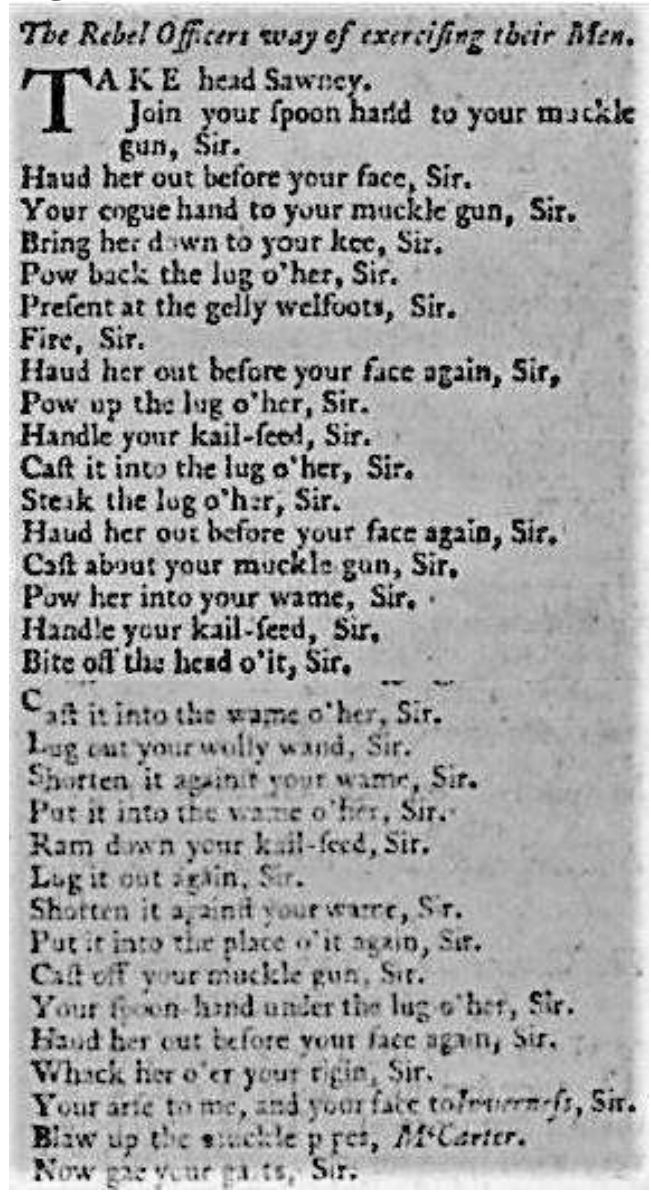

Copies of that 1746 edition seem lost, but evidence supporting Smollett as author of the doggerel in A full, particular, and true Account, is that, in 1743-1746 he did publish other pieces in Scots dialect. One in The Gentleman's Magazine, March 1743, p. 154, titled, The Scotsman's Yearning, described his 1740 visit to Dublin, seeking to meet Jonathan Swift. In Scots Magazine, November. 1743, p. 524, he published, A speciemen of the dialect spoke in some country places of Scotland. Two others written in Scottish dialect bracket the timing of the 1746 advertisement for A full, particular, and true Account. In The Gentleman's Magazine, 1746, on p. 379, is an Epitaph on a Litigious Scotsman, and on p. 643, The Rebel Officers way of exercising their Men (Figures 8 and 9).

A thesis by Mary Gordon Rorke discusses a second, 1752, edition of A Full, Particular and True Account of the Rebellion ..., printed for, and sold by Dougal Graham, Glasgow; and Alexander Young, Stirling, 1752 (Rorke 2017, Smollett 1752B). The thesis promotes the proposition Graham was a real person, and wrote the verses in doggerel. However, the thesis omits discussion of a parallel, but different, London edition of the same 1752 date, also by D. Graham; An impartial history of the rise, progress and extinction of the late rebellion in Britain in the years 1745 \& 1746 ... by D. Graham, Falkirk, T. Johnston, 1752 (ESTC): original unsighted, and queried in some sources, but analysis here supports its existence 
(Smollett 1752A). The former is in Scots dialect, whereas the latter is in English, and key to unmasking the real identity of 'Dougal Graham'.

Despite the DNB claim "as the undoubted testimony of an eye-witness", there are reasons to believe Dougal Graham was a Smollett pseudonym. Perhaps a local identity known to Smollett, but offered as an ironic straw-man, in publishing An Impartial History. T. Johnston being a spurious London imprint, and Falkirk a red-herring location. The work was published in London in 1752, shortly ahead of Smollett's 1753 visit to Scotland. This paper analyses the origin and authorship of the London edition of An Impartial History, and therein scrutinises the claim for Graham as author of A Full, Particular and True Account. In Collected Writings, MacGregor seems unaware there were two 1752 works. He quotes the 1774 edition of An Impartial History, and accepts it differs from A Full, Particular and True Account. MacGregor's remarks in Collected Writings merit caution, and a need to carefully assess their credibility;

As for the second edition of the History of the Rebellion, published in 1752 ... Its tone is indicated by the remark made by $\mathrm{M}^{\prime}$ Vean:-The History of the Rebellion, published by Dougal in 1752, differs very much from the third edition, published in 1774 ... In 1752 Dougal talks of the rebels with a great deal of virulence, in 1774 he softens his tone, and occasionally introduces apologies for their conduct (MacGregor 1883, p. $33)$.

Graham has provided only one or two details about himself ... All beyond what is to be gained from these sources is tradition or inference, and not a little of what has thus been put on record has been questioned. ... Graham is not known to have made any effort in the direction of literature. ... The capacity in which he became attached to the Prince's forces has been matter for conjecture. His physical deformities are assumed to have unfitted him for active service, and everything points to the conclusion that he was not a soldier, but rather a sutler, or camp-follower. ... An event of the first importance in Graham's life was his appointment to the post of skellat bellman of the city of Glasgow ... it is surprising that no notice is taken in the Town Council Records of Graham's incumbency (MacGregor 1883, pp. 11-19).

The DNB and MacGregor statements act as red flags. If the verses in dialect are claimed as, "the undoubted testimony of an eye-witness", who was "not a soldier, but rather a sutler, or camp-follower", and "a bit wee gash bodie under five feet", as lame in one leg, "with a large hunch on his back, and another protuberance on his breast"; they wave a large red flag of ironic satire. It is not credible that, within five months of Culloden, sutler Graham had the knowledge and resources, to research in sufficient detail, and write "an Account of every Battle, Siege, and Skirmish that has happened in either Scotland or England".

So why Smollett? Although omitted from Knapp's biography, there are indications Smollett traveled after Culloden, to Carlisle and Glasgow, returning by sea. The visit is reconstructed, in part, from his contributions in The Gentleman's Magazine, 1748: pages 562-563, has a letter of 9 June 1746, dated Carlisle describing a journey from Derby to Carlisle, both key to the rebellion. The Gentleman's Magazine, 1748, pages 1-5, and 289-292, has a letter of August 1746, attributed to Smollett, describing a coastal voyage south from Carlisle. Smollett 
did accept a work in Scots dialect would not sell in England, so passed his 1746 manuscript to James Duncan of Glasgow for publishing. Smollett later published a separate account in English as, An Impartial History in 1752 with T. Johnston as publisher and Falkirk as the purported location (Smollett 1752A).

Smollett was from Glasgow; he was conversant with the local accent and history, also the Jacobite Rebellion, British and European politics, and with military service as a navy surgeon at Cartagena. Smollett was classically educated by the polemicist author, John Love; “The headmaster of Dumbarton's school was John Love (1695-1750) the celebrated controversialist and grammarian, and also clerk of the presbytery of Dumbarton" (Knapp 1949, p. 8). Examples in this paper confirm Smollett as poet, polemicist, and satirist.

Much academic attention is directed at the verses of An Impartial History but, for Smollett, analysis of the full preface reveals his authorship. It is similar in style to other prefaces he wrote, with reference to Duke William [of Orange] alluding to the knighting of Sir James Smollett, Commissioner for Scotland at the Act of Settlement. Reference to "an Eye-Witness" alludes to eye-witness accounts Smollett drew from the London Gazette. The language is that of a classically educated scholar, claiming to be wit and grammarian; via references to Voltaire, noted as a wit, and Zoilus, the Greek grammarian. With an implied wink, he hints he is "the Author of Ascanius," and acknowledges a debt to Defoe's Memoirs of a Cavalier via, "let Cavillers rather write a better one". He declares "an Itch for Scribling" and proclaims, "I have wrote it in Vulgar Rhyme ... those of common Education like myself". With "like myself" as a truthful, but misleading, redherring; although he studied theology, Smollett never attained a degree;

It is grown customary to introduce New Publications ... with some kind of Oration in their Favour ... I too have my Reasons .... First then, I have an Itch for Scribling, and having wrote the following for my Pleasure. ... Duke William, once the Idol of the loyal British, is gone to the house of Silence ... I have impartially related all that to me seemed worth while, of the Actions of either Party in that confused Fray, from the Writings of the Celebrated Voltaire, from the Author of Ascanius, or from my own Observation, having been an Eye-witness to most of the Movements of the Armies... I have wrote it in Vulgar Rhyme, being what not only pleased my own Fancy, but what I have found acceptable to the most part of my Countrymen, especially to those of common Education like myself. ... Therefore, let Cavillers rather write a better one, than pester themselves and the Public with their Criticisms of my Faults.- To the candid Public, I beg leave to present it, such as it is, and if they applaud, let Zoilus carp his fill—I have gained my End (MacGregor 1883, pp. 83-84). 


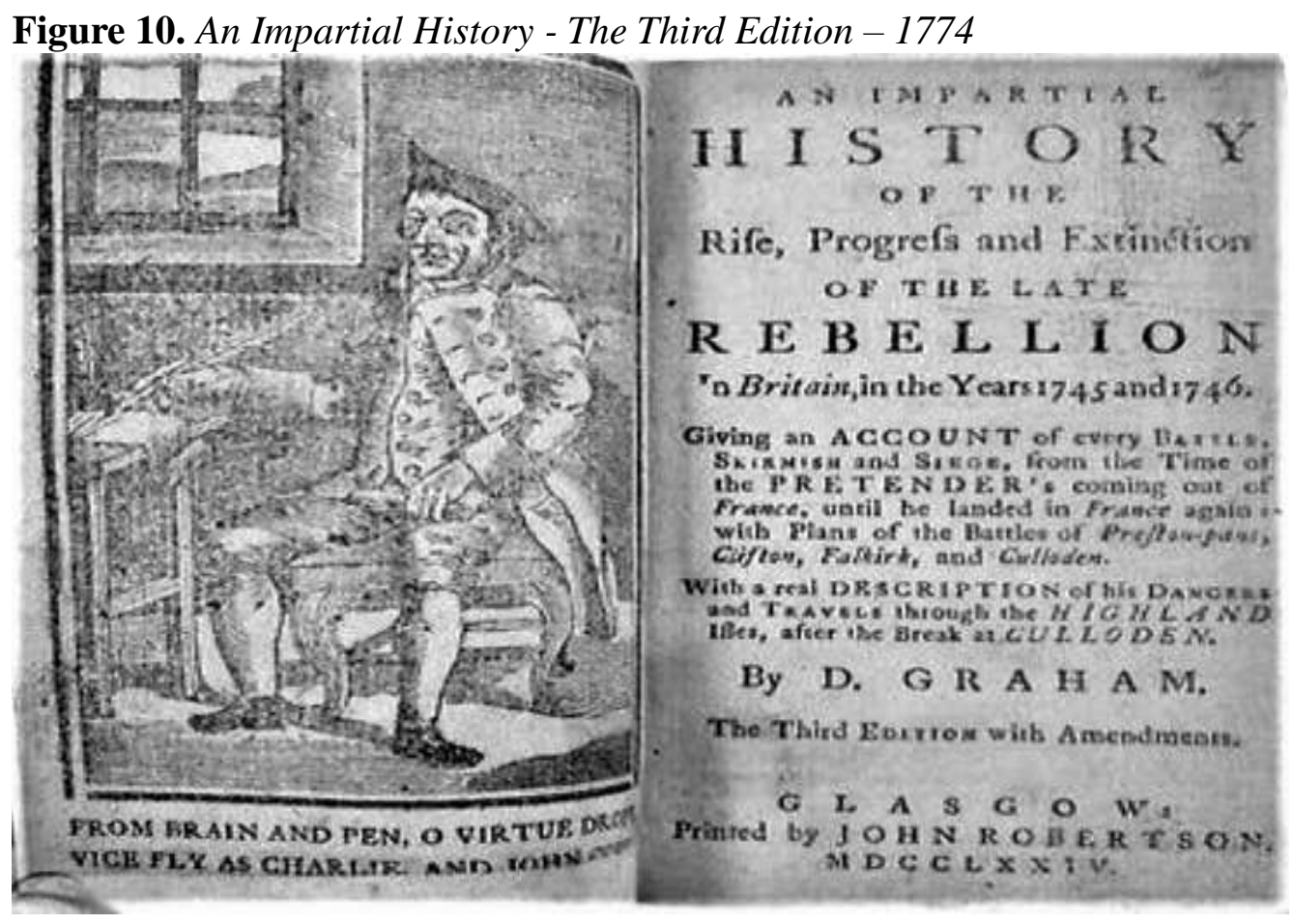

Reprints of An Impartial History by D. Graham, include a third edition of 1774, published by John Robertson in Glasgow for a wider Scottish public; a generation after the Rebellion when emotions had calmed (Figure 10). Aside from the preface, the verses within An Impartial History and in A Full, Particular and True Account betray both works, attributed to Graham, as instead the pen of an educated poet, with knowledge of Latin, British and European politics, of Scotland, the Rebellion, and of recent events in London, and with military experience, also familiar with the local dialect.

Some later chapbook pieces attributed to Graham are likely by Smollett, e.g. The copy of a letter from a gentleman in Scotland to Lewis XV. present King of France, Glasgow, 1755 (Smollett 1755). If Graham was, as claimed, a sutler or chapman, why describe himself there as gentleman? After logical analysis, the attributions to Graham are rejected, as beyond his capability or education. Thus to seek out the identity of Graham, one needs to follow the clue left by Smollett in the Preface to An Impartial History, "the Author of Ascanius". Ascanius pairs with An Impartial History, via their sharing of a T. Johnston spurious imprint.

\section{Ascanius; or the Young Adventurer - 1746}

Ascanius deals with the escape of the Young Chevalier after Culloden, April to September 1746. Apart from An Impartial History in 1752, the only works in 17301770 bearing the spurious imprint of T. Johnston are two versions of, Ascanius, or, the young adventurer; a true history ... London, T. Johnston: one in 1746 of 288pp. and a reprint in 1747 of 185pp. (Smollett 1746A) (Figures 11 and 12). 
Figure 11. Ascanius - T. Johnston 1746

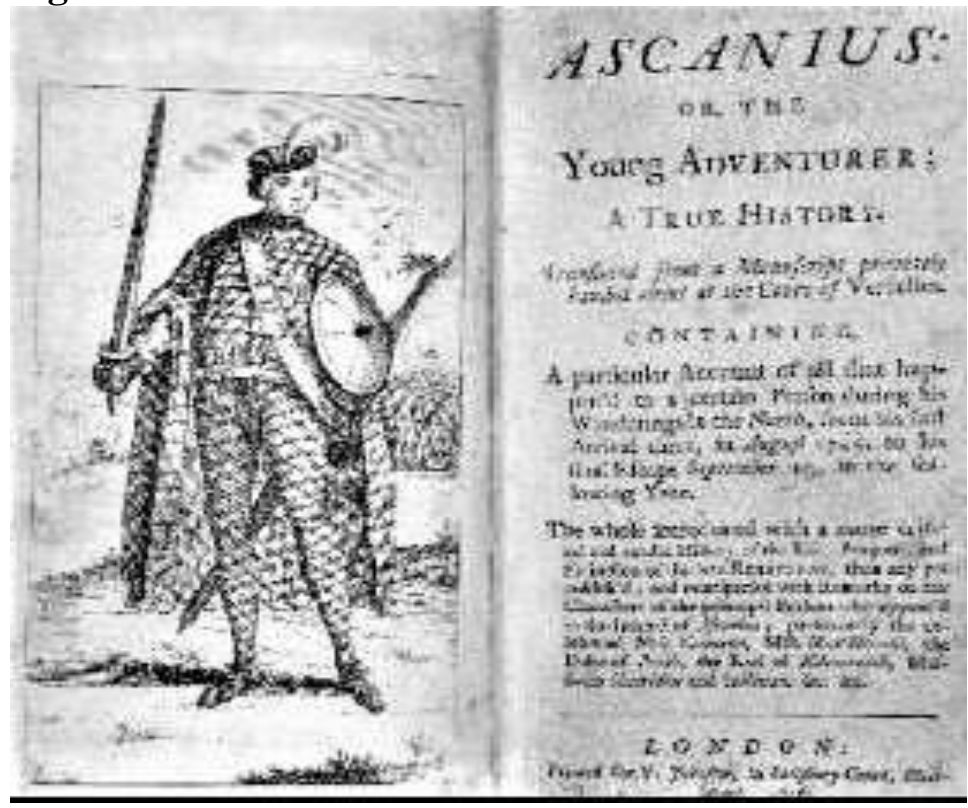

Figure 12. T. Johnston 1747

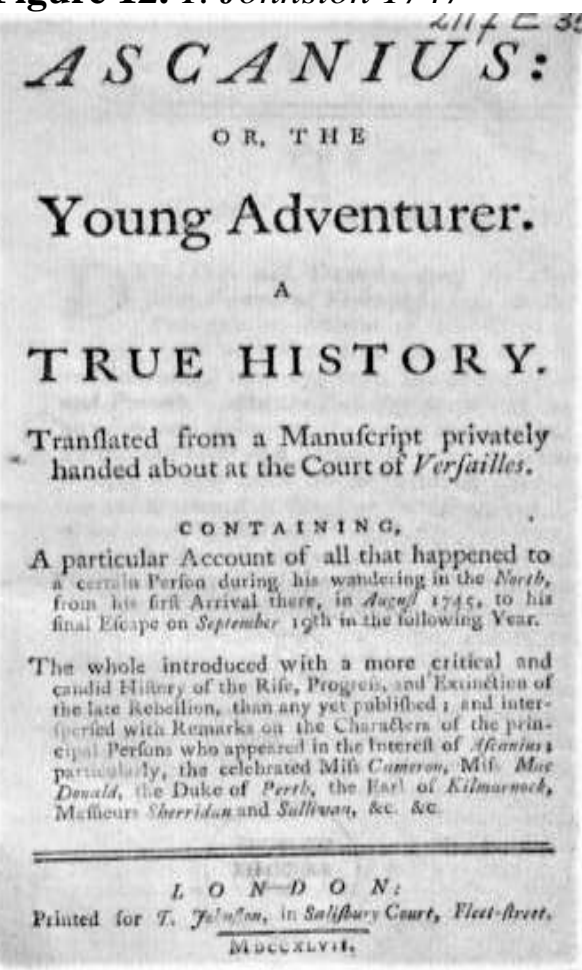

Two shorter, 64pp. versions of Ascanius, with a 1746 Amsterdam imprint, did precede T. Johnston, one was; Ascanius; or The young adventurer, a true history, Translated from a manuscript privately handed about at the Court of Versailles, London, Grimky and Voguel Booksellers in Amsterdam ..., [1746], 64pp. (Figure 13) (Smollett 1746B). The second had the same title, but was printed for G. Smith, Grimky and Voguel [1746] (Figure 14) (Smollett 1746C). The various imprints 
imply a single author published with both G. Smith and T. Johnston; an initial short version, but then expanded as more evidence of events emerged.

G. Smith was spurious in c.1746-1762; as a pseudonym often used by Smollett. The Grimky and Voguel imprint is also false, the actual printer and publisher being William Faden and William Owen. Logical as, in 1747, W. Owen published for Smollett; Reproof: a Satire. The Sequel to Advice, London, W. Owen, (Smollett 1747D). Prior to that, Mary Cooper had published Advice: a Satire for Smollett (Smollett 1746G).

The expanded, 288pp. edition of Ascanius was popular and re-appeared in 1747 as; London, printed for the Proprietor, and sold by R. Griffiths, at the Dunciad, 1747, 288pp. (Smollett 1746D) The imprint clearly notes the proprietor (Smollett), as distinct from the seller. That edition of Ascanius was published soon after Griffiths set up in business; he having earlier worked for Jacob Robinson, who published many titles for Smollett.

When the administration expressed concern, the 1747 imprint led them to Griffiths. As a result, Griffiths, Faden, and Owen were examined for seditious libel at Whitehall Cockpit on 9 January 1746/7 (O.S.). When examined, Griffiths protected the identity of Smollett by declaring he had, composed the said Pamphlett from the accounts of the Rebellion published in the London Gazette, and from other newspapers; as indeed Smollett had done. Griffiths sent a letter of apology (likely composed by Smollett) to the Duke of Newcastle on 13 January, stating, I did not intend to give the Government one moment's uneasiness; and thus enabled Smollett to remain incognito. This court case led to the erroneous attribution to Griffiths.

Figure 13. Ascanius - Amsterdam

\title{
$A S C A N I U S$; \\ OR THE \\ Young Adventurer,
}

\author{
A TRUEHISTOR Y. \\ Tranfated from a Manu/cript privately banded \\ about at the Court of Verfailles. \\ C O N T A I N I G \\ A Particular Account of all that happened to \\ a cerfain PERson turing his Wanderings in \\ the Nortb, fom his memorable Defeat in \\ April $\times 746$, to his final Efcape, on the $x g$ th \\ of September in the fame $\mathbf{Y}$ ear. \\ Ecce Fromo I \\ L O NDON : \\ Printed and Sold by Meffrs. Grrmkx and \\ VoouxL Bookfellers in Amfterdam; and by \\ all other Bookfellers in Great-Britain, Ireland \\ and Holland.
}


Figure 14. Ascanius - Smith

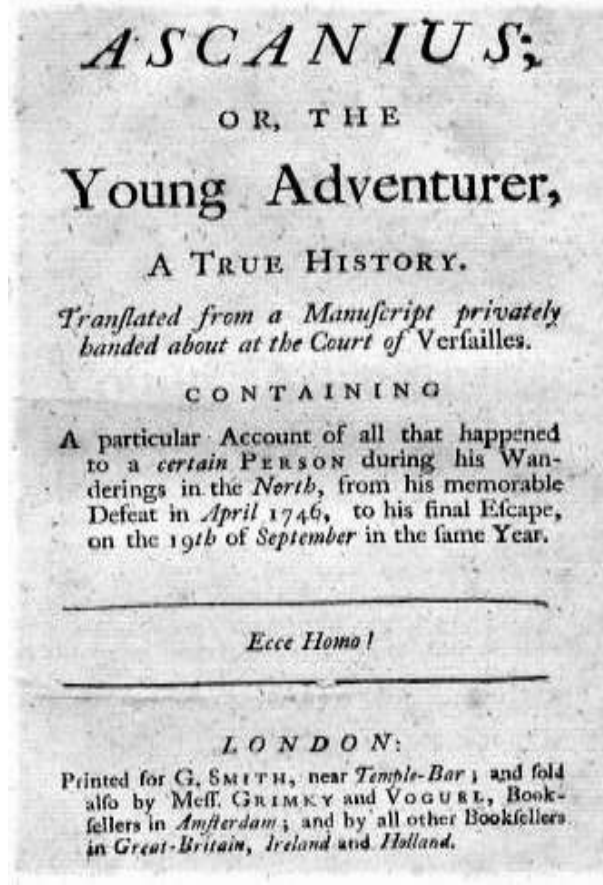

Logically, the puffing of Ascanius in the preface to An Impartial History, ruled out Welshman Griffiths as author of Ascanius: trained as a watchmaker, he was neither classically educated, nor equipped to versify An Impartial History in a Glasgow dialect; as in A Full, Particular and True Account. Lack of a Glasgow dialect, also rules out John Burton (1710-1771) of York, who is sometimes attributed with Ascanius.

The evidential factors combine to describe the author of Ascanius, as an experienced and influential Scottish poet, author, and satirist, classically educated, located in London, knowledgeable on Scotland and the Rebellion, and fluent in a Glasgow dialect. Having military experience, familiar with the subterfuge of Amsterdam and other spurious imprints, also the ploy of, "a manuscript privately handed about at the Court of Versailles," but one who preferred anonymity. Those factors allow an Ascanius attribution to Smollett.

\section{The Wanderer: or, Surprizing Escape - 1747}

In following Defoe's example, a characteristic of Smollett was writing multiple pieces on a subject. Hence, one should expect at least one more prose narrative puffing Ascanius. In 1746, such a work appeared, with a 60pp. version "printed, and sold by the booksellers of town and country," preceding a 1747 Jacob Robinson edition of 104pp.; The Wanderer: or, surprizing escape ... with some Remarks on a Romance called Ascanius, London, Jacob Robinson, 1747 (Figure 15). Clues to Smollett are the title puffing of Ascanius, and Jacob Robinson as publisher. It was typical of Smollett to pretend criticism of another of his works, to draw attention to it, and so encourage sales. The Wanderer dedicates a dozen pages 
of puff to Ascanius, with reference to "such a prodigious run" and the government displeasure with Griffiths, including:

I ran over the pamphlet carelessly enough, looking upon it as calculated to get a penny, without any other view; and thought it, by the turgid stile, the performance of a certain female author [Eliza Haywood], till I had gone through the whole; but then as I found it contained no smutt, I altered my opinion, and throwing it aside, troubled my head about neither the work, nor the author, till I read in the news, that the bookseller of it was taken up. ... I am really apt to think, the bookseller informed against himself, that he might be taken up, as all the public papers would, by that method, advertise his work for nothing... The author sets out with a florid common place soliloque; after which he prudently precautions his readers not to be overcurious in their enquiries; and tells them, in heroics, from whence he derives his commission, by whose authority he takes upon him the mournful task, and how he learnt the sad particulars, are secrets .... Though I must admire the quaint diction of this author, yet I cannot entirely depend on his veracity ... (Smollett 1747A, pp. 1-12).

A word search of The Wanderer for Smollett polemic fingerprints, reveals six instances of "nay" and two of "in a word." The Wanderer uses material drawn from The Gentleman's Magazine, and London Gazette, also military investigations, and from talking to participants. Taken with twelve pages of puff, the knowledge of Scotland and its nobility, it is logical to accept that Ascanius and The Wanderer were by a single author: the obvious candidate being Smollett; already credited with Ascanius, and aided by Jacob Robinson, who published multiple works for Smollett.

\section{A Journey Through Part of England and Scotland - 1747}

Ascanius and The Wanderer are about the Young Pretender, but neither is a close parallel for the pseudo-camp-following Dougal Graham of An Impartial History. Thus worth looking for a Smollett pseudo-camp-follower or soldier, but writing in prose, rather than in verse. He emerges, as "A Volunteer," on the titlepage of a second edition of; A Journey through part of England and Scotland ... By a volunteer. Comprised in several letters to a friend in London, London, T. Osborne, 1747 (Figure 16) (Smollett 1747B). As with An Impartial History it is not credible a volunteer soldier would, or could, have accumulated the detailed history recounted in A Journey. A Journey links to Smollett via his customary, "letters to a friend in London," as used for A Letter from a Physician and Letters from a Gentleman. It is also relevant that the first edition of A Journey was "printed by J. Stanton", with J. Stanton a spurious imprint in 1745-1747, and almost an anagram for the spurious T. Johnston (Smollett 1746H). 
Figure 15. The Wanderer Jacob Robinson

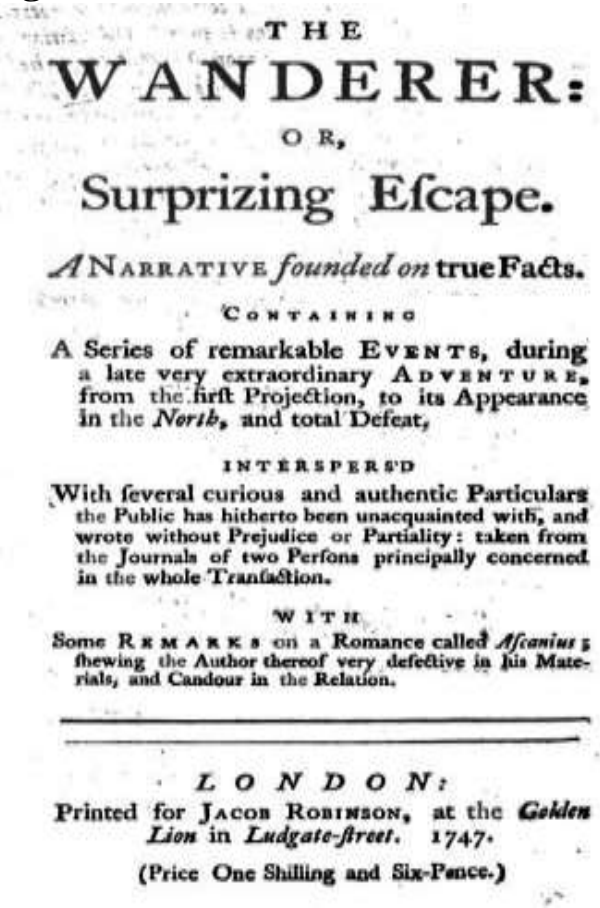

Figure 16. A Journey T. Osborne

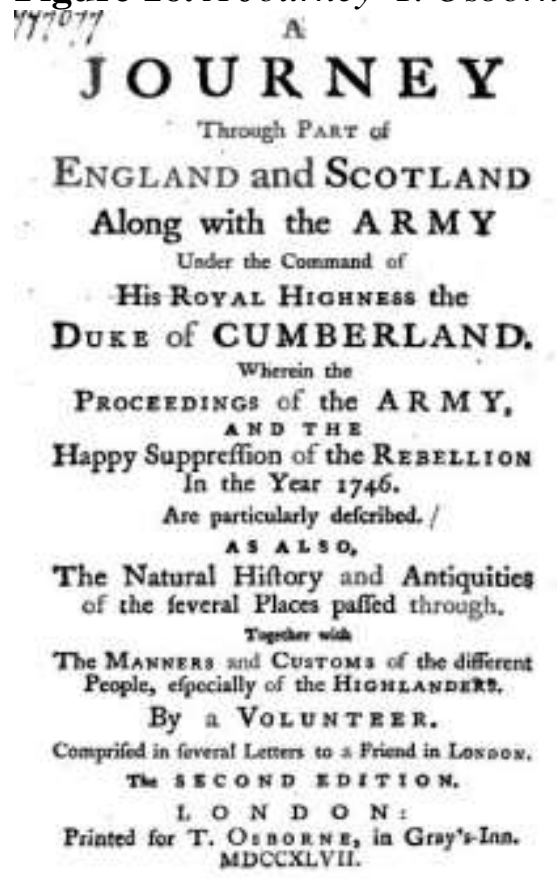

A Journey also connects to Smollett's above-mentioned letter in The Gentleman's Magazine of 9 June 1746, describing a journey from Derby to Carlisle by horse; two cities key in the rebellion, as places for Smollett to seek witness accounts. A polemic hint frequently met in Smollett is "nay", and $A$ Journey uses the term on five occasions. It is not until the volunteer is close to Scotland, that Smollett draws on detail from the London Gazette, to interweave 
witness and combatant accounts. A Journey purports to be the narrative of a serving soldier, but instead follows Smollett's Letters from a Gentleman, as a travelogue gleaned from local guide-books;

Sir, After a most fatiguing Campaign in Flanders, we arrived at Gravesend the fifth of November, 1745, and so after a short stay about London, we were ordered to march for Coventry and Litchfield: In our Rout thither we passed through Hammersmith, Acton, Brentford, \& c. which being so commonly known to the Inhabitants of London, I think needless to describe; and next to Uxbridge, a very long Town seated on the River Coln, having plenty of extravagant Inns. After passing which River, we enter the County of Bucks, and pass through Chafforn, a small Village, and so to Amersham, a Borough Town, twenty-nine measured Miles from London, situated in the Chiltern, (that is, a Part of the County abounding in chalky Hills, covered with Woods and Groves of Beeches); for, in ancient times it was so thick with Trees, that they rendered it impassable, so it served as a common Harbour for Thieves. From thence to Missenden, a good Thoroughfare, having formerly a Monastery, founded by the D'oilys, and augmented by the noble Family, sirnamed De Missenden. Four Miles further, we come to Wendover, a small Borough Town, and then to Alesbury, forty-four Miles from London ... (Smollett 1747B, pp. 3-5).

Leask (2020, p. 69) remarks, "A Journey ... has on the face of it more in common with the prejudiced tone of Burt's Letters"; a perceptive remark, but ignoring the probability the two similar Scottish travelogues, both ironically mocking Highlanders, were authored by satirist Smollett.

Figure 17. Alexis: Or the Worthy Unfortunate, 1747

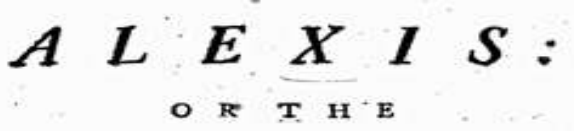

WORTHY UNFORTUNATE.

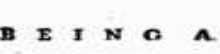

T R U E N A R R A T I V E

- F T H E

A F F E TING CASE

YOUNG GENTLEMAN,

Whofe RUIN was occafioned by the late

R E B E L L I O N.

Who can fucb Woes relate, witbout a Tear,

As fern Ulyffes muft bave vivept to bear?

VIRG. $A$ N.

$I O N D O N=$

Printed for J. С о в А M, near St. Paul's, MDCCXLVIT. 
Figure 18. Alexis: Or the Young Adventurer, 1746

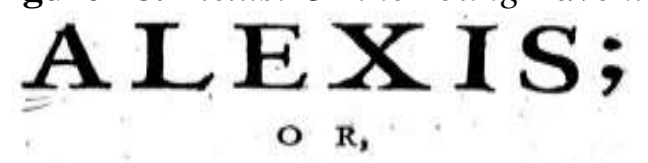

The Young Adventurer:

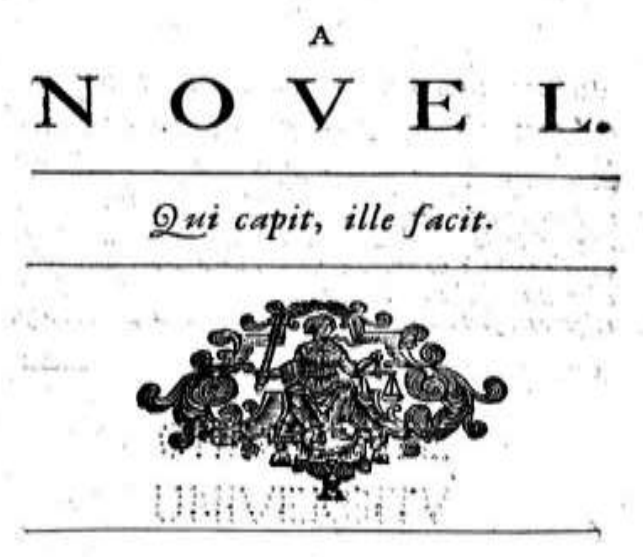

$\begin{array}{lllllll}L & O & N & D & O & N\end{array}$

Printed for T. Cooper. MDCCXLVI,

Detailed research notes (Shelton 2015) attribute many more works on Scotland to Smollett, including two polemic examples espousing opposing views; Alexis; or the Worthy Unfortunate ..., London, J, Cobham, 1747 (Figure 17), with J. Cobham spurious in 1747-51 (Smollett 1747C). And, Alexis; or, The Young Adventurer, London, T. Cooper, 1746 (Figure 18) (Smollett 1746E). The latter is dated three years after Cooper's death, but by using a T. Cooper imprint, Smollett sought to add credence to a purported pre-1745 origin. The work includes an opening note; "The following Piece seems to have been the Product of some leisure Hours. It has been written some Years ago, for it was with Difficulty that it could be transcribed" (Smollett 1746B).

\section{The History of Jack Connor - 1752}

The attributions to Dougal Graham of An Impartial History and A Full, Particular and True Account, and of Edmund Burt to Letters from a Gentleman, have been rejected, as names of minor historical figures. In a like position is William Chaigneau, a minor figure in Ireland; claimed by Ian Ross (Ross 2013), as author of The History of Jack Connor, London, W. Johnston (Figure 19) (Smollett 1752D). Ross shows a William Chaigneau existed, but presents no evidence of content, language, style, nor comparable works, to support Chaigneau as author of Jack Connor. Instead relying on a much later, 1790, rumour noted by Tate Wilkinson, "Chaigneau ... He wrote, for his amusement, the novel in two volumes called Jack Connor". Ross lists many Jack Connor Smollett similarities, but fails to recognise they signal Jack Connor as a Smollett political satire; one involving 
Scotland, Ireland, Fielding, and the Fool. The references in Jack Connor to surgeons, physicians, and medicine, are a reminder Smollett was a surgeon, whereas Chaigneau was not.

Figure 19. Connor Johnston 1752

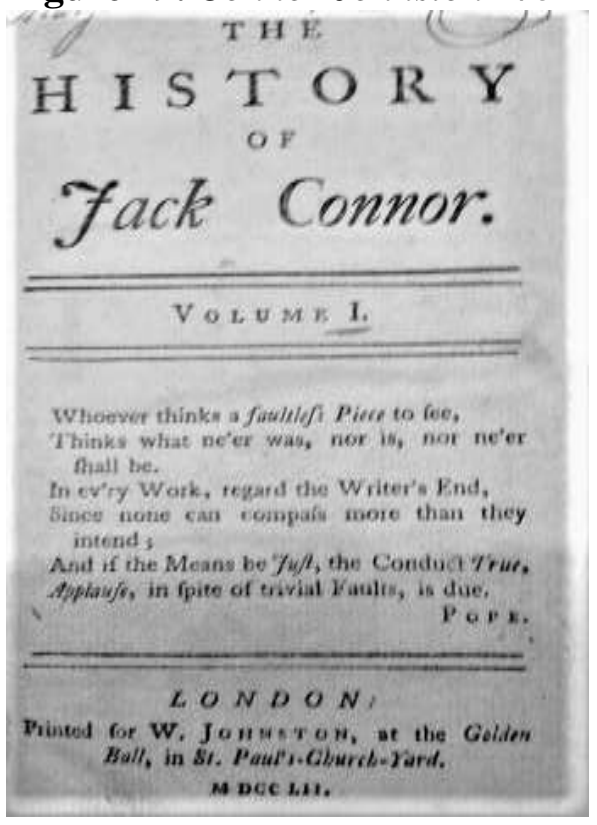

Figure 20. Fathom Johnston 1753

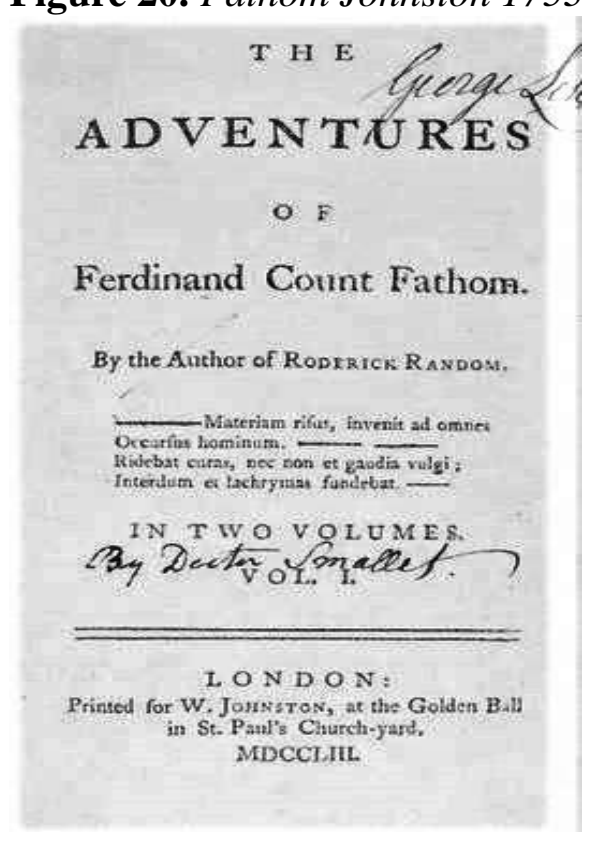

Any publishing connection between T. Johnston, publisher of Ascanius and An Impartial History, and W. Johnston, publisher of Jack Connor, is unclear, but as W. Johnston began publishing in 1748, the T. Johnston Ascanius imprints of 1746-1747 may have been by W. Johnston for Smollett. W. Johnston does appear on many imprints in 1748-1779, including in 1753 when he published for 
Smollett; The adventures of Ferdinand Count Fathom, London, W. Johnston, 1753 (Figure 20) (Smollett 1753C). This appeared on 15 February, 1753, shortly before Smollett left for Inverness. W. Johnston also published, The expedition of Humphry Clinker, London, W. Johnston, (Smollett 1771): this and Count Fathom being unusual in making title-page hints at Smollett.

Compared here are two editions of Jack Connor; the Dublin edition of 1752 , and the 1753 Dublin third edition corrected (Figures 21 and 22). The 1753 edition of Jack Connor includes, as an appendix, a third edition of Stultus, previously published as, Stultus versus Sapientem, in three letters to the fool, London, J. Bromage, with that imprint spurious (Smollett 1749C).

A question resolved by methodical analysis is: Does Jack Connor reveals signs of Smollett's pen? Jack Connor does contain a dozen of his polemic fingerprints: "nay," "in short", and "in a word", with, as an extra oddity, a change of name from Connor to Conyers during the novel. Smollett was sensitive at his own Glasgow accent, with characters in the satire based on Scots he knew. He especially satirised those who softened their Scots accent, as a means to social success in England. He also sought to needle Fielding by a word-play on Conyers Middleton, a close friend of Fielding. One of many clues laid by Smollett, is a cameo appearance of Tom Smart, as a character in Jack Connor, Vol. II. Smollett's T.S. initials also appear as Thomas à Stupidius, author of Stultus versus Sapientem. Smollett never admitted to writing Jack Connor, as he believed his satiric targeting of Scottish society was too provocative. In Jack Connor Smollett makes an another apocryphal claim to receipt of a cache of old papers and, as a warning, stresses his use of irony;

The Historian ... had a Bundle of Papers left him by a deceas'd Friend ... That the Trifle he now presents to the Publick, has a fair Chance of being impartially dealt with; for, as he is unknown, and will remain so ... Irony, well managed, has ever been a successful Way to fix the attention ... The Purpose of the following History may correspond with an old physical Aphorism, which I apprehend may be found in the Schola Salerni [medical remedies], wrote in the Days of William the Conqueror. (Smollett 1753B).

Figure 21. Jack Connor 1752

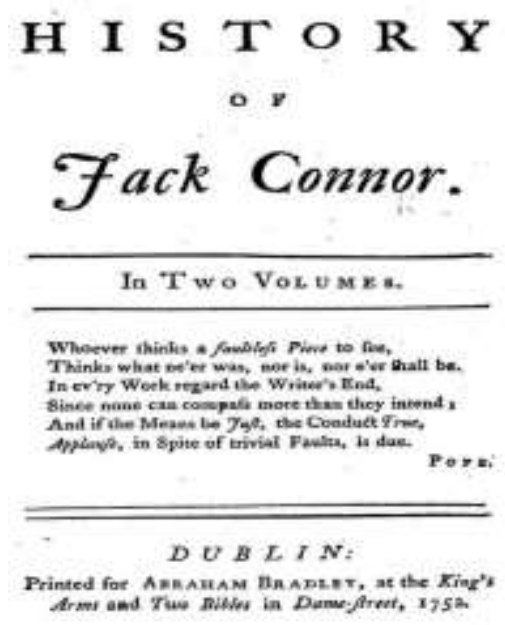


Figure 22. Jack Connor 1753

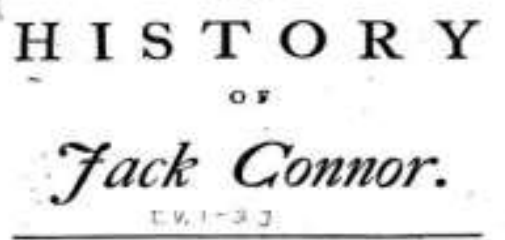

In Two Volumes.

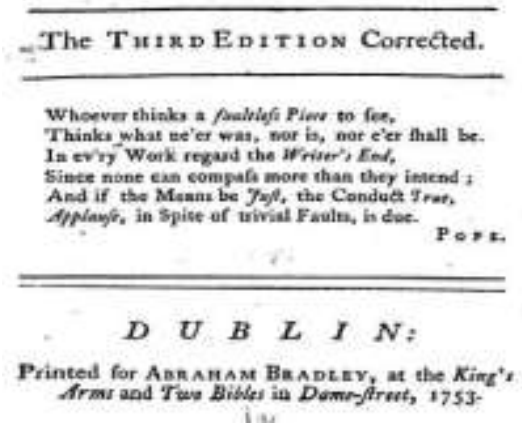

Smollett adds a quote on medical remedies from his contemporary Dr Richard Mead (1673-1754). Smollett had earlier worked for both an apothecary and a surgeon in Glasgow; and selected the Mead quote to reinforce the irony in his Jack Connor satire. In Jack Connor there is satirical mocking of Papists, paralleling Smollett's regular attacks on Jacobites and the French, for their Catholicism. Smollett was of the view Scottish society needed reform to recover from the innate ills contributing to the 1745 Rebellion, but to openly criticise his Scottish kin was clearly unacceptable. To disguise the remedy proposed, he subtly coats it with Irish sugar; "the unpalatable Drug must be convey'd in the most innocent Vehicle his Judgment can furnish". Thus hinting Smollett's references in Jack Connor to Ireland, are really directed at Scotland.

A skilful Physician will consult the Constitution of his Patient, and not madly pour down even the most salutary Medicines. Some Herbs are fill'd with sour, and some with bitter Juices, too disagreeable to be given singly. Physick, like good Counsel, must be administer'd with Caution ... The Patient must must be decoy'd into a Cure, and the unpalatable Drug must be convey'd in the most innocent Vehicle his Judgment can furnish. (Smollett 1753B, pp. vii-viii).

Figure 23. Jack Connor 1st ed. Ashburton

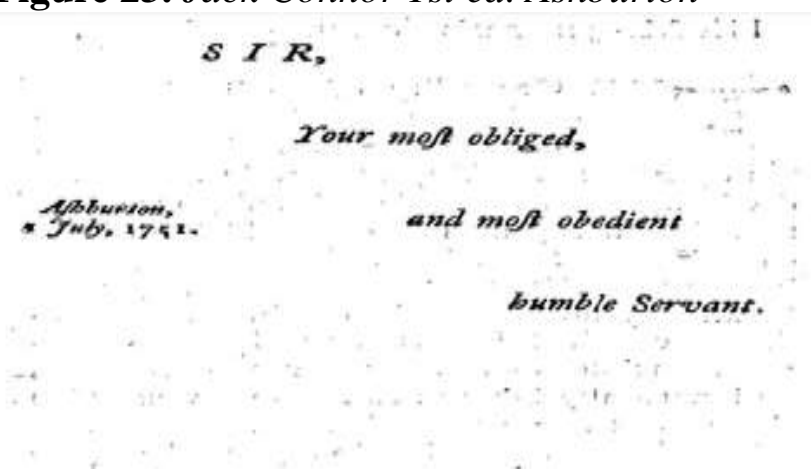


Figure 24. Jack Connor 3rd ed. Dublin, W.C.

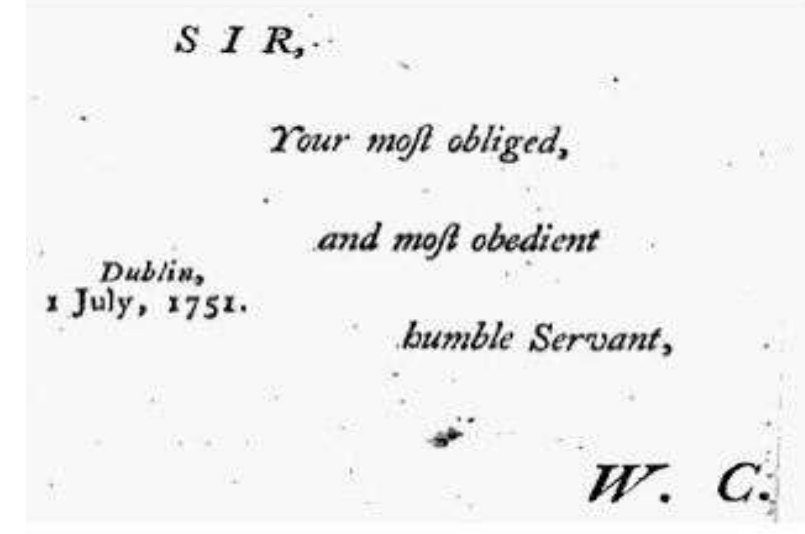

Changes of note in the ironic dedication of Jack Connor, between the first and third editions, are a location change from Ashburton to Dublin; and addition of the initials W.C. (Figures 23 and 24). The dedication in Jack Connor is to Henry Fox, but Chaigneau had no reason to write ironically of Fox, whereas Smollett regularly satirised politicians. Chaigneau is thus eliminated, as a minor historical figure, in the ilk of Dougal Graham and Edmund Burt; elevated by rumour to authorship. Lilliput in Gulliver's Travels is a satire on English politics, with Smollett following Swift; both Jack Connor and Stultus are prima facie picaresque works about Ireland: but the references to Ireland apply equally to Scotland and the Stuart Catholics.

Smollett further hints at his Irish v. Scottish satire, via a carefully chosen titlepage quote from Pope; "In ev'ry Work regard the Writer's End". Smollett's note to the reader, refers to "Irony, well managed"; also to Schola Salerni, and William the Conqueror. A cryptic, and very mischievous, Smollett clue emerges as an ironic double pun on W.C. "curing" religion: not as William in 1066, but as William of Orange, conqueror of Irish Catholics in 1691, and William, Duke of Cumberland, conqueror of Jacobite Catholics in 1746.

A major 1753 change in Jack Connor is the inclusion of, Stultus versus Sapientem: in Three Letters to the Fool, Third Ed. Dublin, 1753, 19pp (Figure 26) (Jumbled page numbers for Stultus in Jack Connor imply a late addition). Analysis of Stultus requires adjudicating on a long-lived literary mystery, a puzzle unaddressed by Ross (2013). Why was Stultus added to Jack Connor? In 1749 E. Bate published Stultus in Dublin showing Henry Fielding as author, but the letters in Stultus are signed Thomas à Stupidius, a clear clue to Tobias Smollett (Figure 25) (Smollett 1749B). A clue to Smollett is on the title-page, as he wrote a regular column for the Daily Gazetteer as The Fool (Shelton 2015). Publisher Bate was thus misled by Smollett about the authorship of Stultus, who intended it as a practical joke directed at Fielding. For, if Fielding was to publicly deny he had written Stultus, he would only focus more attention on it, and so increase its sales.

The 1752 second edition of Jack Connor appeared around the time of Smollett's Habbukkuk Hilding attack on Fielding. After this, Smollett removed Fielding's name from Stultus, and added it into a third 1753 edition, of Jack Connor. Together with an allusion to Jack Connor and Stultus as "Books of Amusement", 
and to "Irony" as a caution to readers the events depicted therein were intended as ironic satire;

The History of Jack Connor having met with so favourable a Reception in Great Britain and Ireland, that my Interest obliged me to give this Third Edition, tho' Books of Amusement, do not generally meet the same Fate. ... I find these Letters were printed in London, in the Paper call'd the Fool ... If Irony, merits your Attention or Regard, these Letters cannot fail of giving you some Pleasure (Smollett 1753B, p. 163).

Figure 25. Stultus Bate Dublin 1749

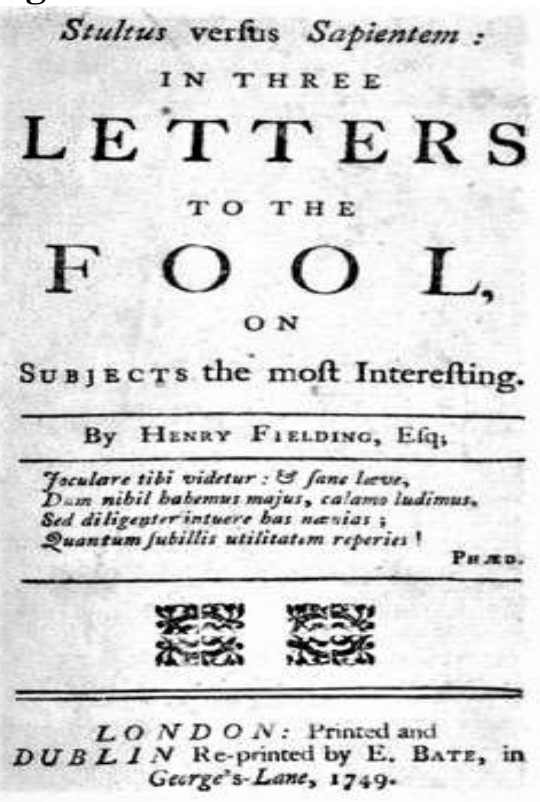

Figure 26. Stultus Bradley 1753

Stultus verfus Sapientem:

I $\mathrm{N}$

Three L E T T E R $S$

$$
\text { TO ТнЕ }
$$

\section{F O O L.}

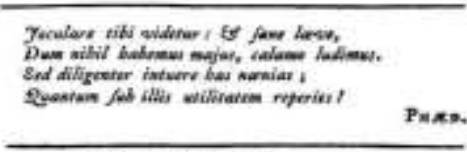

The Third Eprxson.

$\begin{array}{llllll}D & U & B & L & I & N\end{array}$

Printed foe Ananua Brabisr, at the King't

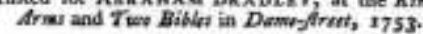


There was a linen industry in Scotland and, in carefully chosen words in Stultus, the kingdom dimensions, 265 miles by 150 miles, apply to Ireland and Scotland; as does a satiric reference to Henry the Second and 1173, when Henry's heir apparent, Young Henry, rebelled, and Scotland, France, Flanders, and Boulogne allied themselves with the Irish rebels. Smollett also alludes to Protestantism, the Scottish Reformation, and the survival of Papism, in both Scotland and Ireland;

I am very well informed that this Kingdom from N. to S. is about 265 Miles, and from E. to W. about 150, and contains about eighteen Millions of statute Acres, with commodious Harbours, Bays, and Rivers. Henry the second stole it from your Ancestors. Many Struggles were made by our good Friends to shake off this Yoke, but in vain. At that Period, vulgarly called The Reformation, your Friends held fast to Mother-Church, but still Protestantism impudently raised her Head, and shamefully flourished (Smollett 1753B II, p. 167).

In 1766 Smollett revised and published a fourth, Dublin edition of Jack Connor (Smollett 1766). Smollett's hand is seen in the revisions, updating political and social events, and in his additions to it: Stultus again, with minor revisions, and adding in two further satires; firstly, The Importance of Ireland to England, and secondly, Motives for a Peace with England, by an Old Sea Officer, in French and English. Naval surgeon Smollett, being obvious as the Old Sea Officer, and Motives for a Peace being previously printed in 1757 for W. Reeve (Smollett 1757), with an extract in London Chronicle, Vol. 2, December, 1757, page 605.

Extended, and uncharacteristically favourable, comments on Jack Connor appeared in the Monthly Review for 1752, pages 447-449. It is believed Smollett wrote those effusive remarks for Ralph Griffiths, prior to their falling out; indicated by Smollett's inclusion, as a puff, in the fourth, 1766, edition of Jack Connor;

This History was first published in 1751. ... This book likewise bore three numerous impressions in London, and met with general applause from all who had any relish for the sentiments of nature. ... the Monthly Review for July 1752 spoke of it in this manner; "Of the several books of entertainment published in the course of the late winter, none gave us more satisfaction in the perusal, than this work ... The author hath taken uncommon and effectual care to conceal his name from the public; ... Guesses, indeed, have been plentifully aim'd at him; but all that these have discovered or agreed in, is, that he appears to be a gentleman, and of a neighbouring kingdom ... Every unprejudiced reader must own, that the stile, and sentiments of this writer speak him to be above the common run of authors" (Smollett 1766, pp. ix-xi).

The case for Smollett as author of Jack Connor is established. As with Dougal Graham, and Edmund Burt, it is irrelevant whether there was a real William Chaigneau, or if Smollett knew him. Based upon the satiric intent, context, content, and style, together with the many literary cross-links, it is contended Jack Connor could not be written by Chaigneau. The details in Jack Connor and Stultus are so connected to Smollett and Fielding, and too interwoven with other events and literary works of 1744-1766, to be penned by an otherwise unremarkable Irish military agent. 


\section{Bampfylde-Moore Carew}

The 1753 change in the dedication of Jack Connor, from Ashburton to Dublin, suggests a Smollett preference to anchor Jack Connor in Ireland. But, why change from Ashburton? Places in Ireland named Ashburton are tiny, whereas Ashburton in Devon is a town on the edge of Dartmoor.

Although a full analysis is outside this paper, Ashburton is near Bickleigh, and shows Jack Connor was conceived in Ashburton at the time Smollett gathered material to revise, An Apology for the Life of Bampfylde-Moore Carew, Son of the Rev. Mr Carew of Bickley... printed by R. Goadby, and sold by W. Owen [1749] (Figure 28) (Smollett 1749A).

This is usually attributed to R. Goadby, but the imprint is categoric, he was the printer, The Ashburton v. Bickleigh locations fit Smollett, as does W. Owen, who published Reproof for Smollett. He is also attributed (Shelton 2015) with an earlier version, The Life and Adventures of Bampfylde-Moore Carew, Esq: Who was King of the Beggers Upwards of 40 Years, London: T Bailey, [1745] (Figure 27). Smollett wrote on Carew, to compete with Fielding's Jonathan Wild, wherein Smollett was ridiculed as Tom Smirk; "The name of this gallant was Tom Smirk. He was clerk to an attorney, and was indeed the greatest beau, and the greatest favourite of the ladies [whores] at the end of the town where he lived" (Fielding 1743, p. 58).

Figure 27. Bampfylde-Moore Carew - Bailey 1745

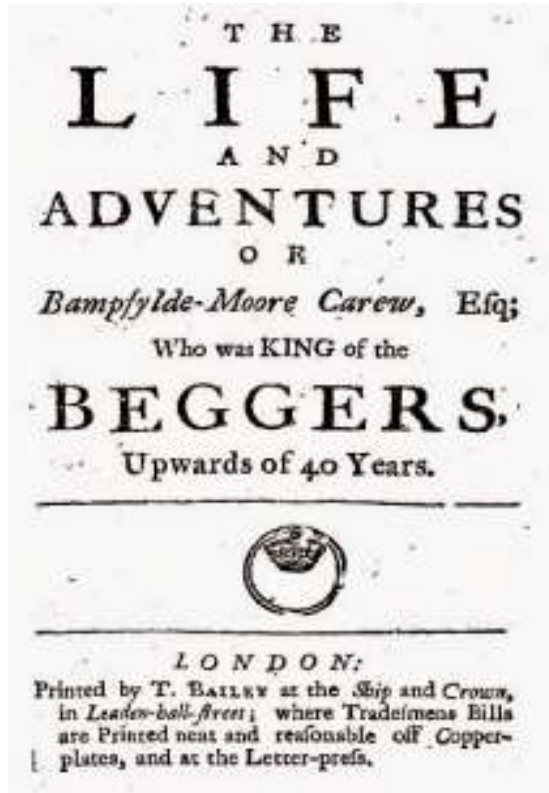


Figure 28. Bampfylde-Moore Carew - Goadby 1749

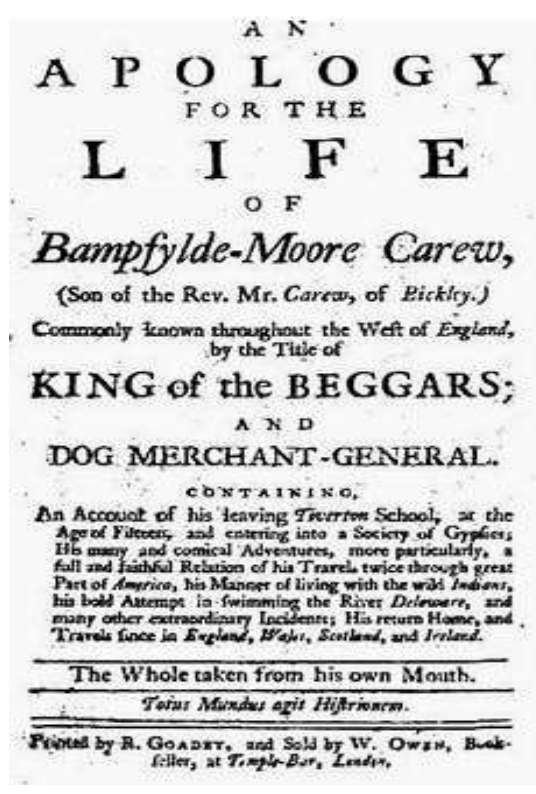

A Second Edition with Additions of An Apology for the Life of BampfyldeMoore Carew, London, printed for R Goadby and W. Owen, 1749, includes a long and fulsome dedication, "To the Worshipful Henry Fielding, Esq;" (Smollett 1749D). This was a Smollett attempt to needle Fielding. He and Smollett exchanged literary barbs for many years, and the dedication in Carew, is a 21 page, puffing and mocking oration at Fielding's expense. That prolix, pedantic, and provocative preface, aids in stamping Smollett as author of Bampfylde-Moore Carew:

Sir, Notwithstanding your constant Refusal, when I have ask'd Leave to prefix your Name to this Dedication, I must still insist upon the Propriety of desiring your Protection of this Work. ... Sir, at the same Time I am praising you, I may find Occasion of saying a few Things of my own great Merit, and that of my Work, by acquainting the World with the high Encomiums you have bestow'd upon it; "for. indeed, what are your Objections to the Allowance of the Honour which I have solicited? Why, you have commended the Book so warmly, that you should be ashamed of reading your Name before the Dedication". Now, Sir, though I don't imagine any of my Readers will understand this Sentence, it being the true Burtonic Sublime, most admirable when least understood, yet, Sir as this Dedication is only intended for you and myself, it is no Matter whether it is understood or not by any one else (Smollett 1749D, pp. iii-xxiv).

\section{The Daily Gazetteer and The Fool}

Little in Jack Connor takes place in Ireland, with the descriptions of Jack's origins and his later return, equally applicable to those of Scottish accent and origin. Many events occur in London or Paris, rather than Dublin. The Wellcome Library holds a letter from Smollett to man-midwife, William Hunter, dated 25 July 1749 (Figure 29). In writing of contemporary Paris events in Jack Connor, the 
Hunter letter evidences Smollett's visit to France where he obtained background. By including Stultus in Jack Connor, Smollett sought to reinforce it as a political satire, with that choice implying Jack Connor and The Fool share a single author. A 360 page collection of The Fool essays was published in 1748; the imprint including; Cooper, Robinson, Corbett, Owen, and Griffiths; all of whom published for Smollett (Figure 30) (Smollett 1748).

Stultus as included in Jack Connor, comprises Three Letters to the Fool (Figure 26). The Fool is often claimed to be William Horsley, but Jack Connor and Stultus rule him out. Fielding was aware of Smollett hiding behind the Horsley name, and chose to make a pun of it. The reason Horsley is assumed to be connected to The Fool, is that, shortly after The Fool essay collection was published, Fielding wrote in The Jacobite's Journal, under the heading, Proceedings at the Court of Criticism. Smollett had a reputation for overuse of scatological references; and, in part 7 of his Proceedings, Fielding resorts to base invective in determining his judgement: "One Horse-piss, alias Horse-dung, alias Horse-lie, alias The Fool, was convicted of Scurrility, and received Sentence of Contempt" (Coley 1974, p. 154). Fielding's soundex pun of "horse-lie" for "Horsley", shows Fielding saw Horsley, The Fool, and Smollett as connected.

Figure 29. Paris, 1749, Wellcome: $7887 / 7$

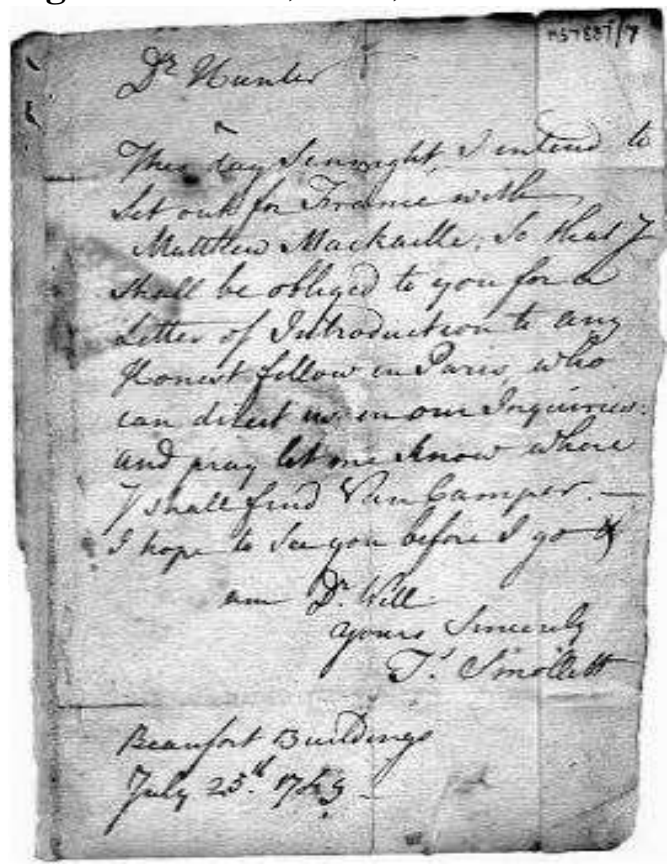


Figure 30. The Fool 1748

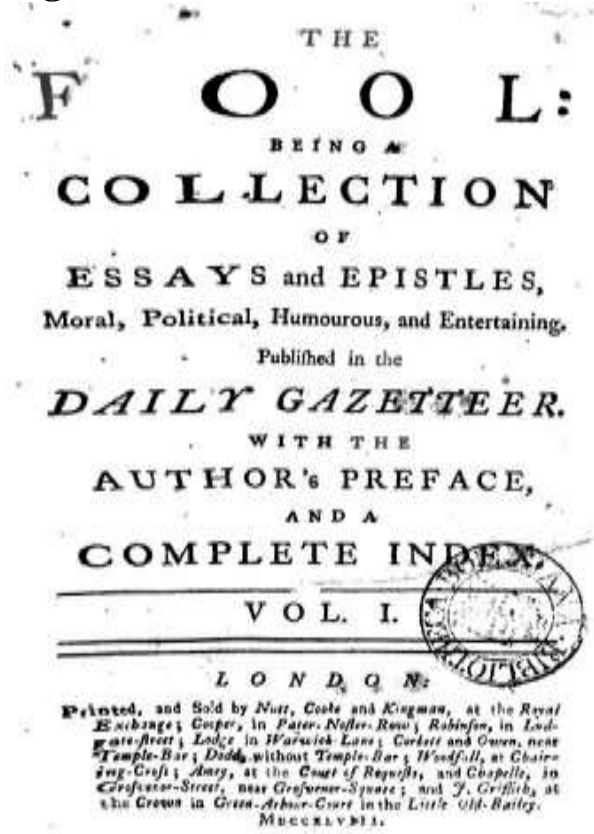

Figure 31. The Mountebank - Lord Bute and Tobias Smollett, as The Fool, Wearing Scottish Plaid, 1762

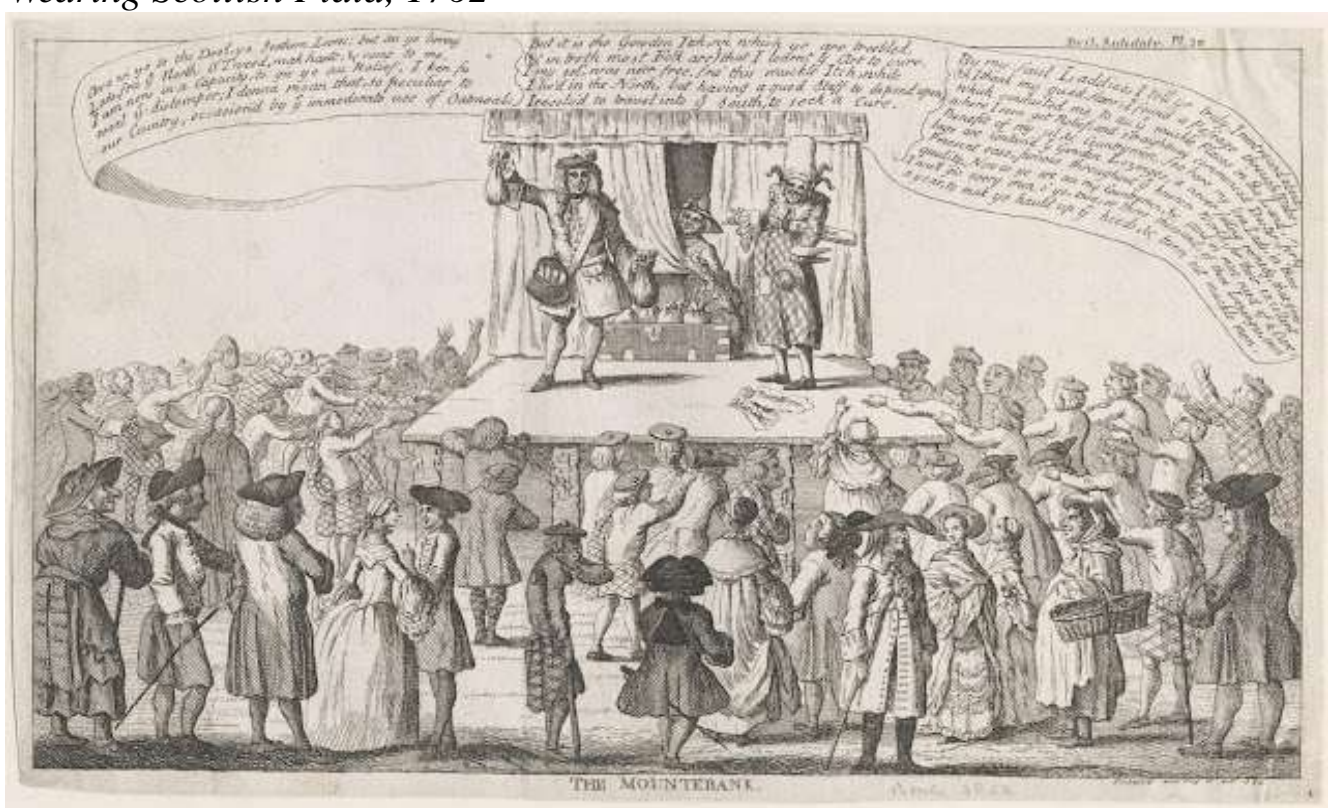

The Fool has been shown as Smollett's pseudonym in the Daily Gazetteer (Shelton 2015), and he was portrayed as The Fool, in a 1762 print, The Mountebank, as recalled by The Gentleman's Magazine;

The historian and pamphleteer, Smollett, who was regarded as the hireling advocate of the Scotch, is introduced in a very amusing way. Lord Bute is the Quack-doctor, boasting of the efficacy of his gold pills; Smollett acts the part of the Mountebank to 
call attention to them. A roll inscribed The Briton is under his arm, while The North Briton lies at his feet (Gentleman's Magazine 1849, p. 234, Figure 31).

Smollett often imprinted spurious works with $\mathrm{Mr}$ and a generic surname, so he could deny any specific person was targeted. For example, but outside this paper's ambit, detailed analysis reveals Smollett wrote the salacious, A Letter from Mr Cibber to Mr Pope, London, W. Lewis, 1742 (Shelton 2015) (Smollett 1742). Two pamphlets, Serious Considerations on the High Duties and A Treatise on Maritime Affairs, do record a Mr Horsley as author in 1744; but the R. Wellington imprint was spurious, as Wellington sold off his entire stock in 1741 (Figures 32 and 33). Smollett spurious imprints also bear names of deceased or retired publishers, so both are attributed to Smollett; using a minor historical figure as cover. As an ex-navy surgeon, Smollett was ever keen to pontificate on the navy, and his ex-navy polemic hand (the first opening with "in a word"), is seen in nautically focused extracts from the two Horsley pamphlets;

In a word, Sir, you have left us in the Condition of an East-India Mariner, who, after a long and tedious Voyage, meets with hazy Weather, attempting to fall in fair with the British Coast, and has nothing to depend upon but a vague and uncertain Reckoning: At length the joyful Noon approaches, the gloomy Clouds separate, and leave a Space, thro' which he discerns the wish'd for God of Day, in full Meridian (Smollett 1744A, p. 2).

You have answer'd the Wish of every Honest Briton, and convinc'd the most haughty of our Neighbours, that Spithead Expeditions are at an end, and that a British Fleet under proper Regulations, and determined Counsels, is design'd for something more important than to blaze in Flags and Streamers, and its Ammunition for something more than Salutes: That Sea-Officers should be better employed than in making Entertainments, and that the Mouths of our Cannon shall at last convince the World our Men of War are not turned into Venetian Gondolas, viz. Vessels for Pleasure and Diversion (Smollett 1744B, pp. 1-2).

Figure 32. Horsley High Duties 1744

$$
8 \mathrm{ER} 10 \mathrm{Us}
$$

CONSIDERATIONS

ON THE

\section{HIGH DUTIES}

E X A M I N'D; ADDPKSBD TO
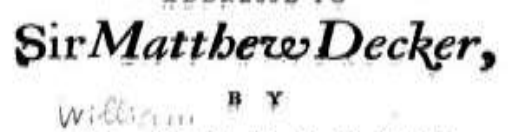

MF. HOR S L E $\boldsymbol{Y}$.

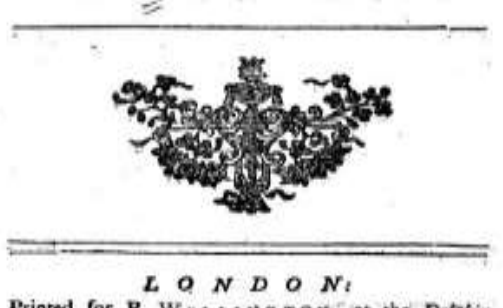


Figure 33. Horsley A Treatise 1744

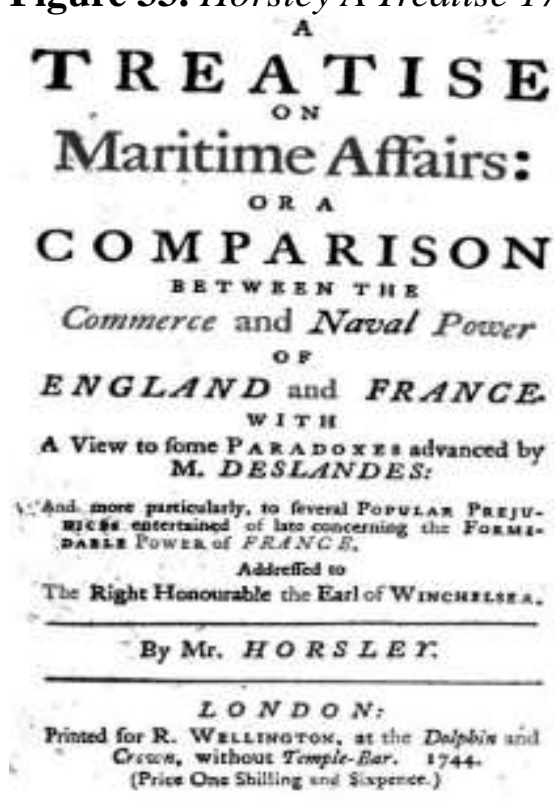

The antagonism between Smollett and Fielding continued over many years and, with Habbukkuk Hilding during the 1752 Paper War, reached one of its several peaks. In seeking to counter Smollett's attacks, Fielding responded via cryptic satire in Amelia, and in Covent-Garden Journal; as discussed in A Satire not a Sermon, Four Stages of Cruelty and Murder (Shelton 2020). Significant also is a Samuel Richardson letter of 21 February, 1752, wherein Richardson conveys how much Fielding despised Smollett:

Mr Fielding has met with the disapprobation you foresaw he would meet with, of his Amelia. He is, in every paper he publishes under the title of the Common [sic] Garden, contributing to his own overthrow. He has been overmatched in his own way by people whom he had despised, and whom he thought he had vogue enough, from the success his spurious brat Tom Jones so unaccountably met, with to write down; but who have turned his own artillery against him and beat him out of the field, and made him even poorly in his Court of Criticism give up his Amelia, and promise to write no more on the like subjects (Edinburgh Review 1805, p. 38).

\section{Conclusion}

The year 2021 is the tercentenary of the birth of Tobias Smollett 1721-1771. Previous academic study of Smollett's early career has been limited, with attention focused on Roderick Random, and his post 1748 career. Reasons for the omissions are unclear, but a contributory factor seems to be that no past study has elected to undertake the raw research needed to uncover the story of Smollett's early literary career. Instead, past studies follow one another, in perpetuating the claim that Smollett left Glasgow in late 1739.

As a result of academic reluctance to scrutinise Smollett, many works, even 
those post 1748, have lain unrecognised among the many anonymous and pseudonymous works published in 1730-1770. That was a neglected opportunity, as the middle eighteenth century, 1730-1770, has a vast amount of easily accessible published material, many works being freely available, in full, on the Internet. In $1730-1770$ it is estimated there are over 20,000 anonymous and pseudonymous works; thousands as contributions to periodicals, but hundreds more as separately published works, and spread across scores of genuine and spurious imprints.

Those spurious imprints are usually ignored in book trade research, being regarded as a complication is attributing works to printers and publishers. Hence their authorship totally ignored. In contrast, in this Smollett research the spurious imprints have been invaluable, allowing testing of a theory that there is a high probability that works sharing a spurious imprint, such as W. Webb, are likely associated with a single author. Similarity of style, theme, language, gutted names, and content within each spurious imprint and its variants has proved the validity of the theory; in turn allowing an extension of the notional Smollett template to identify many of his works within genuine imprints.

From a decade of research, this essay has selected a score of Smollett's midperiod works, describing travels or events, mainly in Scotland, around the time of the Jacobite Rebellion, and has summarised the pro forma case for their attribution to Smollett. Those discussed here are only a small sample of Smollett's corpus, and the freely available open access research notes, demonstrate he sent hundreds of contributions to London periodicals from c.1731, and also authored many, many, separately published works (Shelton 2015).

This attribution of a score of anonymous and/or wrongly attributed, works to Smollett, adds depth and richness to English Literature and the historical record, and it invites scholarly reassessment of much literary, social, and political history in the period $1730-1770$.

The research notes shine new light on literary relationships, and allow new interpretations of material previously ascribed to Pope, Cibber, Fielding, Hogarth, and others. The works discussed here, introduce Smollett as an active and prolific writer on Scotland and the Jacobite Rebellion. They bring to the fore, contemporary comments and prevailing perspectives, on and around events of 1745, by a welleducated, literate, and outspoken Scot: as an author who merits far greater interest from his Scottish homeland, and, with respect to Scottish literature, is believed not inferior to Robert Burns, nor Walter Scott.

\section{References}

Adburgham A (2012) Women in print: writing women and women's magazines from the restoration to the accession of Victoria. London: Faber.

Boswell J (1785) The journal of a tour to the Hebrides with Samuel Johnson. London: Baldwin.

Chantrey D (2009) George Wade - 1673-1748. Ilfracombe: Stockwell.

Coley W (1974) The Jacobite's Journal and Related Writings, Oxford: Clarendon.

Defoe D (1724) A tour thro' the whole island of Great Britain, divided into circuits or journies, giving a particular and diverting account of whatever is curious and worth observation. London, Strahan. 
Defoe D (2006) Memoirs of a Cavalier. Stroud: Nonsuch.

DNB (1900) The dictionary of national biography: from the earliest times to 1900. London: OUP.

Fielding H (1743) The life of Mr Jonathan Wild the Great; miscellanies, volume III. London: Millar.

Johnson S (1775) A journey to the Western Islands of Scotland. Dublin: Walker.

Klukoff P (1968) Smollett and the Sackville controversy. Neuphilologische Mitteilungen 69(4): 617-628.

Knapp L (1949) Tobias Smollett, Doctor of men and manners. Princeton: PUP.

Leask N (2020) Stepping Westward: writing the Highland tour, c.1720-1830. Oxford: OUP.

MacGregor G (1883) The collected writings of Dougal Graham, "Skellat" Bellman of Glasgow: edited with notes. Glasgow: Morison.

Pitcairn R (1833) Ancient criminal trials in Scotland, volume II. Edinburgh: Bannatyne.

Rorke M (2017) A full, particular and true account of the rebellion in the years 1745-1746 by Dougal Graham. The man, the myth and the modus operandi. Glasgow, UK: University of Glasgow.

Ross I (Ed.) (2013) The history of Jack Connor. Portland: Four Courts.

Shelton D (2015) The lost works of Tobias Smollett and the war of the Satirists: www.tobi assmollett.blogspot.com.

Shelton D (2020) A satire not a Sermon: four stages of cruelty and murder. Athens Journal of History 6(3): 223-286.

Smollett T (1737) [Anon] Albania: a poem, addressed to the Genius of Scotland. Dedicated to General Wade. London: T. Cooper.

Smollett T (1742) [Cibber] A letter from Mr. Cibber, to Mr. Pope, inquiring into the motives that might induce him in his satyrical works to be so frequently fond of Mr. Cibber's name. London: Lewis.

Smollett T (1744A) [Horsley] Serious considerations on the high duties examin'd, address'd to Sir Matthew Decker, by Mr. Horsley. London: Wellington.

Smollett T (1744B) [Horsley] A treatise on maritime affairs: or a comparison between the commerce and naval power of England and France. with a view to some paradoxes advanced by $M$. Deslandes. London: Wellington.

Smollett T (1744C) [Anon] The strolling hero, or, Rome's knight-errant. London: M. Cooper.

Smollett T (1745) [Anon] The life and adventures of Bampfylde-Moore Carew, Esq: who was King of the beggers upwards of 40 years. London: Bailey.

Smollett T (1746A) [Anon] Ascanius; or the young adventurer, a true history. London: Johnston.

Smollett T (1746B) [Anon] Ascanius; or the young adventurer, a true history. London: Grimky and Voguel.

Smollett T (1746C) [Anon] Ascanius; or the young adventurer, a true history. London: Smith, Grimky and Voguel.

Smollett T (1746D) [Griffiths] Ascanius; or the young adventurer, a true history. London: the Proprietor and R. Griffiths.

Smollett T (1746E) [Anon] Alexis; or, the young adventurer. London: T. Cooper.

Smollett T (1746F) The tears of Scotland. Edinburgh.

Smollett T (1746G) Advice: a satire. London: M. Cooper.

Smollett T. (1746H) [Anon] A journey through part of England and Scotland. London: J. Stanton.

Smollett T (1747A) [Anon] The wanderer: or, surprizing escape. A narrative founded on true facts. London: Robinson. 
Smollett T (1747B) [Anon] A journey through part of England and Scotland along with the army under the command of His Royal Highness the Duke of Cumberland. London: Osborne.

Smollett T (1747C) [Anon] Alexis; or the worthy unfortunate. Being a true narrative of the affecting case of a young gentleman, whose ruin was occasioned by the late rebellion. London: Cobham.

Smollett T (1747D) Reproof: a satire. The sequel to advice. London: Owen.

Smollett T (1748) [Anon] The fool: being a collection of essays and epistles, moral, political, humourous, and entertaining. Published in the Daily Gazetteer. With the author's preface, and a complete index, London: Nutt.

Smollett T (1749A) [Goadby] An apology for the life of Bampfylde-Moore Carew, son of the Rev. Mr Carew of Bickley. London: Owen.

Smollett T (1749B) [Fielding] Stultus versus Sapientem, in three letters to the fool. Dublin: Bate.

Smollett T (1749C) [Anon] Stultus versus Sapientem, in three letters to the fool. London: Bromage.

Smollett T (1749D) [Anon] A second edition with additions of an apology for the life of Bampfylde-Moore Carew. London: Goadby and Owen.

Smollett T (1752A) [Graham] An impartial history of the rise, progress and extinction of the late rebellion in Britain in the years 1745 \& 1746. London [Falkirk]: Johnston.

Smollett T (1752B) [Graham] A full, particular and true account of the rebellion, giving a full account of all the battles, greatly enlarg'd and corrected by the author Dougal Graham. Glasgow: Graham.

Smollett T (1752C) [Anon] A letter from a physician in the highlands to his friend in London, on the subject of a consumptive habit. London: Corbett.

Smollett T (1752D) [Chaigneau] The history of Jack Connor. London, W. Johnston.

Smollett T (1753A) [Goodwill] The ladies magazine or, the universal entertainer. London: C. Griffith.

Smollett T (1753B) [Chaigneau] The history of Jack Connor. 3rd Edition. Dublin: Bradley.

Smollett T (1753C) The adventures of Ferdinand Count Fathom. London: W. Johnston.

Smollett T (1754) [Burt] Letters from a gentleman in the North of Scotland to his friend in London. London: Birt.

Smollett, T (1755) [Graham] The copy of a letter from a gentleman in Scotland to Lewis $X V$. present King of France, concerning the Wars. Glasgow.

Smollett T (1757) [Anon] Motives for a peace with England addressed to the French ministry. By an old sea officer. London: Reeve.

Smollett T (1763) [Anon] John English's travels through Scotland. Containing, a curious and entertaining account of the manners and strange customs of the inhabitants. With many humorous anecdotes, and natural discoveries. London: Morgan.

Smollett T (1766) [Chaigneau] The history of Jack Connor. 4th Edition. Dublin: Bradley.

Smollett T (1771) The expedition of Humphry Clinker. London: W. Johnston.

Smollett T (1815) [Burt] Letters from a gentleman in the north of Scotland to his friend in London, volume I. London: Gale, Curtis and Fenner.

Smollett T (1818) [Burt] Letters from a Gentleman in the north of Scotland to his friend in London, volume II. London: Best Fenner.

Smollett T (1990) The expedition of Humphry Clinker. Athens: Georgia.

Swift J (1726) Travels into several remote nations of the world. In four parts. By Lemuel Gulliver, first a surgeon, and then a captain of several ships. London: Motte. 


\section{Periodicals}

Critical Review, various.

Daily Gazetteer, various.

Edinburgh Review, 1805.

Gentleman's Magazine, various.

London Chronicle, 1757.

London Gazette, various.

Monthly Review, various.

Notes and Queries, 1859.

Scots Magazine, various. 
